Uluslararası Mühendislik

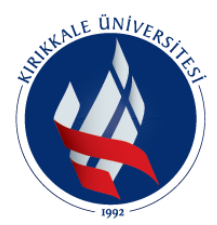

\title{
A Study Toward Analyzing the Energy, Exergy and Sustainability Index Based on Performance and Exhaust Emission Characteristics of a Spark- Ignition Engine Fuelled with the Binary Blends of Gasoline and Methanol or Ethanol
}

\author{
Battal Doğan 1 iD, Murat Kadir Yeşilyurt 2 iD, Derviş Erol *3 iD, Abdülvahap Çakmak 4 iD \\ ${ }^{1}$ Department of Automotive Technology, TUSAŞ-Kazan Vocational School, Gazi University, Ankara, 06500, Turkey \\ ${ }^{2}$ Department of Mechanical Engineering, Faculty of Engineering-Architecture, Yozgat Bozok University, Yozgat, 66200, Turkey \\ ${ }^{3}$ Department of Automotive Technology, Kirlkkale Vocational School, Kırlkkale University, Kirlkkale, 71450, Turkey \\ ${ }^{4}$ Department of Motor Vehicles and Transportation Technologies, Kavak Vocational School, Samsun University, Samsun, 55850, Turkey
}

Başvuru/Received: $29 / 04 / 2020$

Kabul / Accepted: 18/05/2020

Çevrimiçi Basım / Published Online: 30/06/2020

Son Versiyon/Final Version: 30/06/2020

\begin{abstract}
The anxieties regarding global warming upon increasing greenhouse gas emission grades worldwide and the presence of petroleumbased fuels have directed the researchers to focus on the development of biofuels as well as the utilization of reformulated gasoline fuels by adding oxygenated additives resulting in an extensive application to improve fuel properties. In this study, engine performance and exhaust emission tests were performed using pure gasoline and volumetrically $10 \%$ ethanol-C2 or methanol$\mathrm{C} 1 /$ gasoline blends (G100, E10, and M10). The engine experiments for all test fuels were carried out in a single-cylinder, fourstroke, water-cooled, spark-ignition (SI) engine under fixed engine speed (1500 rpm) and various loading conditions $(25 \%, 50 \%$, $75 \%$, and $100 \%$ ). In the tested engine, the brake specific fuel consumption (BSFC) values of G100, M10, and E10 fuels under full load condition were found to be as $0.279 \mathrm{~kg} / \mathrm{kWh}, 0.296 \mathrm{~kg} / \mathrm{kWh}$ and $0.307 \mathrm{~kg} / \mathrm{kWh}$, respectively. When the exhaust emissions were examined, E10 and M10 fuels were observed to have lesser $\mathrm{CO}, \mathrm{CO}_{2}, \mathrm{NO}_{\mathrm{x}}$, and $\mathrm{HC}$ emissions in comparison with pure gasoline. The lowest $\mathrm{CO}$ emission was determined as $3.15 \%$ for E10 fuel at a $75 \%$ load. $\mathrm{NO}_{\mathrm{x}}$ emissions descended with the increase of engine load in all fuel blends meanwhile the best performance is measured as $908.86 \mathrm{ppm}$ in E10 fuel at $100 \%$ load. The minimum HC emission for E10 fuel was measured as $116.36 \mathrm{ppm}$ at a 75\% load. Compared with G100 fuel, E10 and M10 blends emitted 39\% and 35\% fewer $\mathrm{HC}$ emissions, respectively at 75\% load. Besides, E10 and $\mathrm{M} 10$ fuels generated $8 \%$ and 5\% less $\mathrm{CO}_{2}$ emissions at all engine loads, respectively, when compared to G100 fuel. As a result of thermodynamic analyses; The highest exergy efficiency values were found to be at $21.0 \%$ for G100, $17.92 \%$ for E10, and $16.85 \%$ for M10, respectively. Besides, the energy efficiencies were obtained to be as $30.01 \%$ for G100, 28.33\% for E10, and 29.90\% for M10, respectively. According to the sustainability analysis, E10 fuel performed better results than M10 fuel in order to be an alternative to G100 fuel.
\end{abstract}

Key Words

"Spark-ignition engine, gasoline, ethanol, methanol, exergy analysis, sustainability index." 


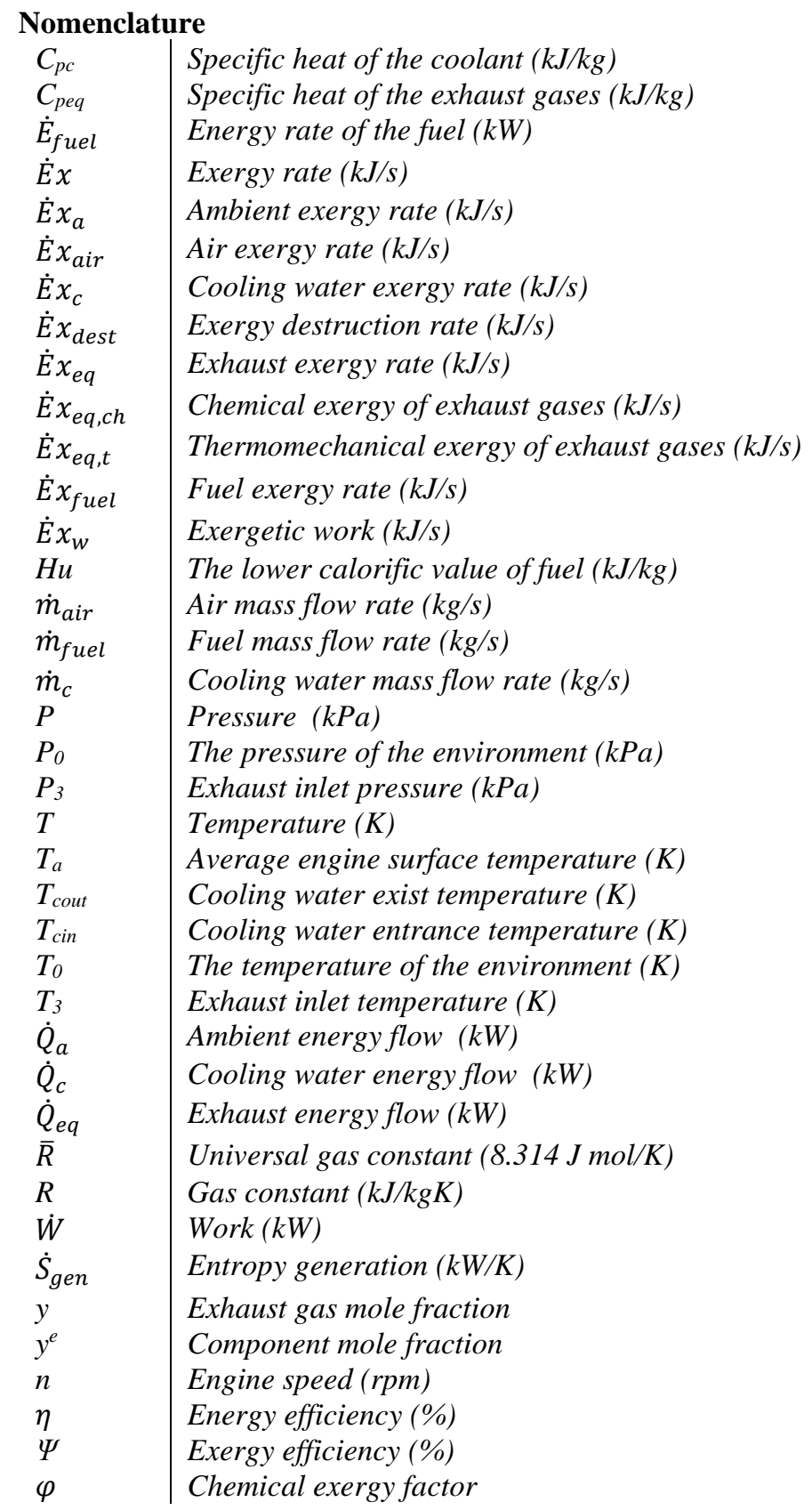

\begin{tabular}{l|l} 
Abbreviations \\
ABDC & After the bottom dead centre \\
$B B D C$ & Before the bottom dead centre \\
ATDC & After the top dead centre \\
$B T D C$ & Before the top dead centre \\
$B T E$ & Brake thermal efficiency \\
$\mathrm{B} 10$ & $10 \%$ butanol $+90 \%$ gasoline \\
$\mathrm{B} 20$ & $20 \%$ butanol $+80 \%$ gasoline \\
$\mathrm{B} 60$ & $60 \%$ butanol $+40 \%$ gasoline \\
$\mathrm{BSFC}$ & Brake specific fuel consumption \\
$\mathrm{C}_{8} \mathrm{H}_{18}$ & Gasoline \\
$\mathrm{CH} \mathrm{H}_{3} \mathrm{OH}$ & Methanol \\
$\mathrm{C}_{2} \mathrm{H}_{5} \mathrm{OH}$ & Ethanol \\
$\mathrm{CO}$ & Carbon dioxide \\
$\mathrm{CO}$ & Carbon monoxide \\
$\mathrm{CR}$ & Compression ratio \\
$\mathrm{EO}, \mathrm{Gl} 100$ & 100\% gasoline \\
$\mathrm{E} 5$ & $5 \%$ ethanol+95\% gasoline
\end{tabular}




\begin{tabular}{l|l} 
E10 & $10 \%$ ethanol $+90 \%$ gasoline \\
E15 & $15 \%$ ethanol $+85 \%$ gasoline \\
E20 & $20 \%$ ethanol $+80 \%$ gasoline \\
E25 & $25 \%$ ethanol $+75 \%$ gasoline \\
E30 & $30 \%$ ethanol $+70 \%$ gasoline \\
E40 & $40 \%$ ethanol $+60 \%$ gasoline \\
E50 & $50 \%$ ethanol $+50 \%$ gasoline \\
E60 & $60 \%$ ethanol $+40 \%$ gasoline \\
E85 & 85\% ethanol $+15 \%$ gasoline \\
E100 & $100 \%$ ethanol \\
EGT & Exhaust gas temperature \\
$H C$ & Unburned hydrocarbon \\
$I C E$ & Internal combustion engine \\
$M 5$ & $5 \%$ methanol $+95 \%$ gasoline \\
$M 10$ & $10 \%$ methanol $+90 \%$ gasoline \\
$M 15$ & $15 \%$ methanol $+85 \%$ gasoline \\
$M 20$ & $20 \%$ methanol $+80 \%$ gasoline \\
$M 25$ & $25 \%$ methanol $+75 \%$ gasoline \\
$M 30$ & 30\% methanol $+70 \%$ gasoline \\
$M 60$ & $60 \%$ methanol $+40 \%$ gasoline \\
$M 85$ & 85\% methanol $+15 \%$ gasoline \\
$M 100$ & $100 \%$ methanol \\
$N_{2}$ & Nitrogen \\
$N O X$ & Nitrogen oxides \\
$O_{2}$ & Oxygen \\
$S 10$ & $10 \%$ solketal $+90 \%$ gasoline \\
$S I$ & Spark-ignition \\
$S I N$ & Sustainability index
\end{tabular}

\section{Introduction}

Energy is needed for areas such as domestic utilization and transportation in daily life. A significant part of the energy demands has been met from fossil-based fuels. As a result of using fossil-based fuels in the internal combustion engines (ICEs), many harmful pollutants, like carbon monoxide $(\mathrm{CO})$, unburned hydrocarbon $(\mathrm{HC})$, and nitrogen oxides $\left(\mathrm{NO}_{\mathrm{x}}\right)$, have been released into the atmosphere (Awad et al., 2018; Barreto, 2018; Mwangi, 2015). Moreover, it is predicted that the reserves of fossil-based fuels will be depleted in the next 50 years all over the world. Such adverse factors have directed the developed countries to alternative, sustainable, and renewable energy resources that can be produced from domestic sources within the country (Bussar et al., 2016; Connolly et al., 2014; Connolly et al., 2016; Hansen et al., 2019; Krakowski et al., 2016; Lund et al., 2009).

Nowadays, alcohol-based choices like ethanol and methanol have been widely preferred instead of fossil-based fuels in SI engines. Ethanol and methanol have attracted more attention due to their advantages, such as less emission in combustion products, high octane numbers, and being able to run without knocking at high compression ratios (CRs) (Chen et al., 2018; Masum et al., 2013; Sayah et al., 2011; Sezer et al., 2013; Zhen et al., 2015).

Methanol and ethanol have been evaluated with blending both pure diesel and gasoline fuels in various proportions without making too many arrangements on the fuel system of engines. The most common ethanol and methanol blend applications have been known as E10 - E85 and M10 - M85, respectively, and they contain 10\% and 85\% of ethanol or methanol, respectively (Elfasakhany, 2017; Thangavelu et al., 2016).

Yücesu et al. (2006) examined the performance and emission values in a single-cylinder, four-stroke, SI engine with ethanol-gasoline fuel blends (E10, E20, E40, and E60) at dissimilar CRs and engine speeds. It could be reported that the infusion of ethanol into gasoline improved brake torque and BSFC along with descended HC and CO harmful exhaust emissions.

Shenghua et al. (2007) experimentally researched the engine performance and emission values in a three-cylinder, four-stroke, SI engine with methanol-gasoline fuel blends with different ratios (M10, M15, M20, M25, and M30) at various engine speeds and full load. The addition of methanol to gasoline led to reduce engine power and torque insignificantly but to decline $\mathrm{HC}$ and $\mathrm{CO}$ harmful exhaust emissions significantly. 
Yanju et al. (2008) performed power, thermal brake efficiency (BTE), and emission features using methanol-gasoline fuel blends at different concentrations coded as M10, M20, and M85, respectively. The researchers stated that the addition of methanol to gasoline descended $\mathrm{CO}$ and $\mathrm{NO}_{\mathrm{x}}$ emissions by $25 \%$ and $80 \%$, respectively.

Bilgin et al. (2008) carried out experimental studies in a single-cylinder, four-stroke, SI engine with methanol-gasoline fuel blends (M5, M10, M15, and M20) at several CRs of 7.5:1, 8:1, and 8.5:1, spark timings of $7.5^{\circ}, 10^{\circ}$, and $12.5^{\circ}$, and engine speeds (900-1600 $\mathrm{rpm})$. The researchers reported that the maximum brake means effective pressure values occurred when the tested engine was run on the M5 mixture. Besides, the highest BTE was indicated to be observed with the M20 fuel blend. Furthermore, the best performance for all spark timings was also noted to be provided with the M20 fuel blend.

Koç et al. (2009) investigated the performance and emission characteristics by conducting experimental studies in a single-cylinder, four-stroke, SI engine with ethanol-gasoline fuel blends (E50, and E85) at different CRs and engine speeds. The researchers noticed that the addition of ethanol to gasoline caused to turn in up the fuel consumption, power, and engine torque as well as reduction in $\mathrm{CO}$, $\mathrm{NO}_{\mathrm{X}}$, and $\mathrm{HC}$ emissions.

Sezer et al. (2009) in their thermodynamic modelling study, worked the utilization of ethanol and methanol as alternating and clean fuels for an SI engine with exergy analysis. The outcomes coming from the analysis showed that the oxygenated fuels were stated to be exergetically appropriate alternatives because of declining heat losses and entropy generation. In contrast to pure gasoline, ethanol and methanol were reported to decrease the irreversibility by $7.44 \%$ and $4.29 \%$, respectively. However, the oxygenated fuels were observed to increase the BSFC and descend the effectual power output.

Eyidogan et al. (2010) examined the performance and combustion characteristic values using ethanol-gasoline blends (E5 and E10) and methanol-gasoline blends (M5 and M10) in a vehicle having a four-cylinder, water-cooled, multi-point injection, SI engine. During the experimental studies, alcohol blends brought about to increase the BSFC and cylinder gas pressures compared to pure gasoline fuel.

Li et al. (2011) converted a single-cylinder, four-stroke, direct-injection, diesel engine into an SI engine by making modifications. They investigated the effects of injection and ignition timings with optimum injection and ignition timings on engine performance and emissions experimentally by using pure methanol as an alternative fuel in the engine SI mentioned above. With this developed test setup, experimental studies were carried out using different CRs and a multi SI system and a single-SI system at a constant engine speed of $1500 \mathrm{rpm}$. According to the outcomes coming from the experimentations, the ignition system, CR, and methanol injector modifications were found to have positive influences on the performance of the tested engine by $27 \%$ in the BTE.

Turner et al. (2011) carried out experimental studies in a single-cylinder, four-stroke, SI engine using E0, E10, E20, E30, E50, E85, and E100 fuels at different spark ignition timings along with a constant engine speed of $1500 \mathrm{rpm}$. They examined the performance and exhaust emission behaviours. According to the obtained results, it was to be noted that with the increase in the ratio of ethanol in the fuel blends, the combustion rate and in-cylinder gas pressure increased, and $\mathrm{CO}, \mathrm{NO}_{\mathrm{X}}$, and $\mathrm{HC}$ emissions decreased.

Schifter et al. (2011) investigated the effects of ethanol-gasoline blends (E10, E15, and E20) on the brake power, BSFC, and exhaust emission characteristics in a single-cylinder, electronically-controlled, SI engine by performing experimental studies at a constant engine speed of $2000 \mathrm{rpm}$ for different lambda values. Since the energy content of the E20 fuel blend was $8 \%$ less than that of pure gasoline, the BSFC was determined to be higher, approximately 6\%. The addition of ethanol to gasoline was observed to decline $\mathrm{CO}$ and $\mathrm{HC}$ emissions while increasing $\mathrm{NO}_{\mathrm{x}}$ emission.

Ozsezen et al. (2011) studied the performance and exhaust emissions of the vehicle running on ethanol-gasoline blends (E5 and E10) and methanol-gasoline blends (M5 and M10) at various speeds (from $40 \mathrm{~km} / \mathrm{h}$ to $100 \mathrm{~km} / \mathrm{h}$ ) in a vehicle with a four-cylinder, SI engine. During the experimental studies, alcohol blends were determined to increase BSFC and wheel power compared to pure gasoline fuel. Moreover, in all of the tests conducted with alcohol-gasoline blends, it was noticed that $\mathrm{CO}$ emission increased while $\mathrm{HC}$ emissions decreased in comparison with pure gasoline.

In the experimental study conducted by Farkade et al. (2012) the performance and emission values by blending butanol, ethanol, and methanol alcohol fuels with gasoline at different ratios $(10 \%, 20 \%$, and $30 \%$ by volume) were investigated. In general, the researchers detected that lower $\mathrm{CO}$ and $\mathrm{HC}$ emissions along with higher carbon monoxide $\left(\mathrm{CO}_{2}\right)$ emission were generated as a result of more stable combustion of the fuels inside the cylinder. This situation was because of the increase in the number of oxygen molecules due to the aforementioned three different tested fuel mixtures when compared with the neat gasoline fuel. Besides, they stated that the M30 fuel blend exhibited the best engine power performance compared to other fuel blends and that the lowest fuel consumption, as well as the best thermal efficiency, were provided with the M10 fuel blend.

Gravalos et al. (2013) researched the exhaust emission properties of low and high molecular weight alcohol-gasoline fuel blends in a single-cylinder, two-stroke, SI engine. The results showed that among the harmful exhaust emissions, $\mathrm{CO}$ and $\mathrm{HC}$ emissions decreased. In contrast, $\mathrm{NO}_{\mathrm{X}}$ and $\mathrm{CO}_{2}$ emissions increased in comparison with pure gasoline regarding the increase in alcohol content in the blend fuels. 
Canakci et al. (2013) investigated the BSFC, exhaust gas temperature (EGT), and harmful exhaust emissions using ethanol-gasoline blends (E5 and E10) and methanol-gasoline blends (M5 and M10) in a vehicle operated with a four-cylinder, water-cooled, multi-point injection system, gasoline engine at speeds of $80 \mathrm{~km} / \mathrm{h}$ and $100 \mathrm{~km} / \mathrm{h}$. The findings exhibited that $\mathrm{CO}, \mathrm{CO}_{2}, \mathrm{HC}$, and $\mathrm{NO}_{\mathrm{x}}$ emissions decreased at a speed of $80 \mathrm{~km} / \mathrm{h}$ while CO emission increased at a speed of $100 \mathrm{~km} / \mathrm{h}$. The researchers stated that the highest emission values among alcohol-gasoline fuel blends were found with the M10 fuel blend.

Altun et al. (2013) investigated the impacts of using 5\% and 10\% ethanol or methanol in gasoline on the engine performance and exhaust emissions by conducting experimental studies at different engine speeds and $75 \%$ throttle opening. According to the experimental results, it was determined that for all alcohol-gasoline tested fuels, $\mathrm{CO}$ and $\mathrm{HC}$ emissions decreased compared to pure gasoline fuel while the BSFC, BTE, and $\mathrm{CO}_{2}$ emission increased. In contrast to pure gasoline, the use of E10 and M10 fuel blends in the tested engine led to a decrease in $\mathrm{HC}$ emissions by $15 \%$ and $13 \%$, respectively, and CO emissions by $9.8 \%$ and $10.6 \%$, respectively. The best results were observed to be in the E10 and M10 fuel blends in terms of emissions.

Agarwal et al. (2014) conducted experimental studies in a four-cylinder, four-stroke, water-cooled, Maruti Suzuki Zen 2001 model SI engine with methanol-gasoline blends (M10 and M20) at various engine speeds and loads. They scrutinised some parameters, such as BSFC, BTE, EGT, cylinder pressure, and harmful emissions. Based on the results, the researchers reported that methanol-gasoline fuel blends had higher BTE compared to pure gasoline. In addition, they observed that $\mathrm{CO}$ and $\mathrm{NO}_{\mathrm{X}}$ emissions decreased. The researchers stated that when the combustion characteristics of methanol-gasoline fuel blends were compared to those of pure gasoline, almost similar values were obtained.

Balki and Sayin (2014) studied the performance, combustion characteristic and harmful exhaust emission values of a single-cylinder, air-cooled, four-stroke, SI engine fuelled with pure methanol (M100), ethanol (E100), and gasoline (G100) fuels under a constant engine speed of $2400 \mathrm{rpm}$ with different CRs. The researchers found that BTE and volumetric efficiency in pure ethanol and methanol alternating fuels were occurred to be higher than those of pure gasoline for all CRs. Besides that, the BSFC increased as expected due to the lower calorific values of ethanol and methanol compared to pure gasoline. Moreover, the usage of pure ethanol and methanol for all CRs caused drop the $\mathrm{CO}, \mathrm{HC}$, and $\mathrm{NO}_{\mathrm{x}}$ emissions.

Balki et al. (2014) tested methanol (M100), ethanol (E100), and gasoline (G100) fuels in a single-cylinder, air-cooled, four-stroke, Datsu LT 200 model SI engine at several engine speeds so as to investigate the influences of alcohol-based fuels on the BSFC, engine torque, BTE, EGT, cylinder gas pressure, and harmful exhaust emissions. The outcomes demonstrated that the usage of alcohol fuels led to increasing engine torque, BSFC, BTE, and combustion efficiency values. Furthermore, they observed that the utilization of pure ethanol and methanol reduced $\mathrm{CO}, \mathrm{HC}$, and $\mathrm{NO}_{\mathrm{x}}$ emissions and that it increased $\mathrm{CO}_{2}$ emission due to combustion recovery.

Ghazikhani et al. (2014) calculated the exergy terms after experimentally determining the emission amounts in a two-stroke engine operating with alcoholic fuel additives (E5, E10, and E15). The experiments were carried out between $2500 \mathrm{rpm}$ and $4500 \mathrm{rpm}$ engine speed intervals. It has been determined that the irreversibility increased in alcoholic mixtures and therefore, the second law efficiency turned down. The formation of pollutants like $\mathrm{HC}, \mathrm{CO}_{2}, \mathrm{CO}$, and $\mathrm{NO}_{\mathrm{X}}$ was substantially dropped when the tested engine fueled with the addition of ethanol to gasoline in all test conditions.

Elfasakhany (2014) examined volumetric efficiency, brake power, engine torque, BSFC, EGT, cylinder pressure, and emission characteristics of a single-cylinder, air-cooled, four-stroke, SI engine operating with ethanol-gasoline blends (E3, E7, and E10) at different engine speeds. The experimental findings demonstrated that volumetric efficiency, brake power, engine torque, EGT, and cylinder pressure values increased for all test fuels, and BSFC decreased in comparison with pure gasoline fuel. Furthermore, CO and $\mathrm{HC}$ emissions were decreased. As a result of this study, the fuel blend exhibiting the best performance values considering all experimental parameters was stated to be the E10 blend.

Elfasakhany (2015) compared the performance and exhaust emission behaviours of an SI engine powered with ethanol-gasoline and methanol-gasoline blends, including 3-10 vol.\% alcohol concentration. It was to be noted that alcohol-treated fuel blends reduced CO and $\mathrm{HC}$ emissions. Also, the lowest emission values and highest power values were obtained with methanol-gasoline blends among alcohol-gasoline fuel blends.

Kapusuz et al. (2015) performed the effects of the use of ethanol-gasoline blends (E5, E10, and E15) and methanol-gasoline blends (M5, M10, and M15) on the engine performance of a single-cylinder, SI engine at different engine speeds (1000-2500 rpm) by applying an artificial neural network model that they developed.

Wu et al. (2016) investigated the impacts of methanol and gasoline (M100 and G100) fuels on the combustion characteristics and exhaust emissions of a four-cylinder, continuous variable valve timing, SI engine by conducting experimental studies at idle engine speed $(800 \mathrm{rpm})$ for different lambda values $(\lambda=1.0,1.2$, and 1.4). According to the results, they reported that the use of pure methanol reduced $\mathrm{CO}, \mathrm{HC}$, and $\mathrm{NO}_{\mathrm{X}}$ emissions. Methanol fuel was stated to provide higher BTE than that of pure gasoline fuel. 
Li et al. (2017) observed the effects of using ethanol-gasoline blends (E10, E30, and E60), methanol-gasoline blends (M10, M30, and M60) and butanol-gasoline blends (B10, B30, and B60) on the performance, and harmful pollutants under a constant engine speed of $1200 \mathrm{rpm}$ with full throttle opening. The researchers indicated that the lowest $\mathrm{NO}_{\mathrm{x}}$ emission values were obtained with methanolgasoline fuel blends, while the lowest $\mathrm{HC}$ emissions were obtained with ethanol-gasoline fuel blends. Furthermore, it was reported that butanol-gasoline fuel blends provided lower BSFC compared to pure gasoline fuel.

Alexandru et al. (2017) conducted experimental studies in a single-cylinder, four-stroke, Honda CN 250 model gasoline engine using methanol-gasoline blends (M5, M10, M15, M20, and M25) at various engine speeds and loads to investigate the engine performance and harmful exhaust emission characteristics. They explained that methanol-gasoline blends reduced engine power and torque by about $10 \%$ while also reducing $\mathrm{CO}$ and $\mathrm{HC}$ emissions significantly. Moreover, methanol-gasoline blends were stated to ensure $13 \%$ higher $\mathrm{CO}_{2}$ emission compared to pure gasoline fuel.

Doğan et al. (2017) performed exergy and energy analyses of a four-cylinder, four-stroke, SI engine operating with gasoline-ethanol mixtures (E10, E20, and E30). Hence, the exergy amounts lost by the exhaust, cooling water and radiation were calculated in each fuel. The most considerable exergy destruction occurred in neat gasoline while the maximum exergy efficiency was found to be at 53\% in the E0 fuel at $3000 \mathrm{rpm}$ along with minimum exergy efficiency was observed to be like $45 \%$ in the E30 fuel at $4500 \mathrm{rpm}$.

Mithaiwal et al. (2017) performed an exergy analysis based on the engine performance results using both 100\% ethanol and ethanolgasoline blends (E25 and E40). The results exhibited that the mechanical efficiency values decreased by 10-16\% for E25, 9-5\% for E40, and 5-3\% for E100 at different loads as compared to E0 fuel. The exergy efficiencies reduced by 3-5\% at medium load for the entire ethanol-gasoline mixture. On the other hand, the availabilities of E25, E40, and E100 fuels increased by 9-13\%, 13-19\%, and 3$5 \%$, respectively, when compared to pure gasoline under variable load conditions.

Hasan et al. (2018) carried out experimental researches in a single-cylinder, air-cooled, four-stroke, SI engine using alcohol-gasoline blends which contained $10 \%$ and $20 \%$ ethanol at different CRs and a constant engine speed of $2500 \mathrm{rpm}$ with full load conditions. The researchers investigated the effects of ethanol-gasoline blends on the BTE, BSFC, and harmful exhaust emission values. Based on the results, the CR had essential influences on harmful pollutants. It was indicated that $\mathrm{HC}$ and $\mathrm{CO}$ emissions were affected very little by a change in the $\mathrm{CR}$ and that the $\mathrm{NO}_{\mathrm{x}}$ emission values increased a lot in the emission amount depending on the increase in the $\mathrm{CR}$. The lowest $\mathrm{HC}$ and $\mathrm{NO}_{\mathrm{x}}$ emissions were obtained with the E20 blend at 4:1 of the $\mathrm{CR}$ while the lowest $\mathrm{CO}$ emission was observed with the E10 blend.

Özcan and Çakmak (2018) investigated the influences of oxygenated fuel additive-gasoline blends involving 10\% (by volume) ethanol (E10), methanol (M10), and solketal (S10) on the exergy parameters in an SI engine. With the use of oxygenated fuel additives, the maximum cylinder pressures increased, but exergy efficiencies decreased in comparison with pure gasoline. The researchers reported that the maximum decrement in the exergy efficiency occurred as $8.42 \%$ with S10 fuel. It was explained that maximum irreversibilities occurred with pure gasoline fuel, and minimum irreversibility occurred with E10 fuel. However, oxygenated fuel additives were observed to reduce the first law efficiency.

Tian et al. (2020) conducted a study in a four-cylinder, water-cooled, turbocharged, four-stroke, SI engine implementing the GT-Power simulation platform. In the trials, ethanol-gasoline blends (E10 and E20), methanol-gasoline blends (M10 and M20), and butanolgasoline blends (B10 and B20) were used depending on different engine speed, load, flame kernel radius, and ignition time values. In this simulation study, they investigated the effects of different alcohol-gasoline blends on the BSFC, BTE, EGT, and harmful exhaust emission values.

In recent years, the studies on engines have been based on reducing exhaust emissions, increasing efficiency, and minimizing power losses. When the researches in the literature have been meticulously reviewed, it has been reported that many works and developments have been carried out on the use of ethanol and methanol alcohols in SI engines. These studies have been observed to aim at determining the performance and emission characteristics mainly. Exergy analysis studies involving the use of ethanol-gasoline and methanolgasoline blends in SI engines have been limited (Doğan et al., 2017; Ghazikhani et al., 2014; Mithaiwal et al., 2017; Sezer et al., 2009). For this reason, in the present study, the performance and exhaust emissions obtained by using pure gasoline, ethanol-gasoline, and methanol-gasoline blends at different loads in an SI engine were experimentally determined. By using experimental data, energy, exergy, and sustainability analyses were conducted. Exergy performance in the case of using two different alcohol-based fuel blends as an alternative fuel instead of gasoline was investigated. In the study, it was determined which alcohol-based additive would be suitable as alternative fuel instead of gasoline by using sustainability analysis. In the fuels used in the test engine; Exergy losses from the exhaust, coolant, and engine body were analyzed. In addition, entropy production resulting from irreversibilities was detected in all engine loads. 


\section{Material and Methods}

\subsection{Data preparation}

In experimental studies, three different fuels, namely pure gasoline (G100), 90\% gasoline - 10\% ethanol (E10), and 90\% gasoline $10 \%$ methanol (M10), were used. Pure gasoline with octane number 95 used in this work was procured from a local petroleum station in Samsun, which is one of the leading fuel companies in Turkey. The fuel mixtures were prepared by splash blending technique with adding 99\% purity ethanol and methanol to gasoline to obtain the fuel mentioned above mixtures. The physical and chemical properties of pure gasoline, ethanol, and methanol are presented in Table 1. The highest carbon content in fuel mixtures used in the test engine is in G100 fuel. The amount of oxygen contained in the fuel is high in methanol. While the densities of methanol and ethanol are very close to each other, both fuels have a much higher density than gasoline. Gasoline's lower heating value is $37.3 \%$ and $53.4 \%$ higher than ethanol and methanol, respectively.

Table 1. Technical properties of fuels (Shenghua et al., 2007; Sezer et al., 2013; Elfasakhany, 2015)

\begin{tabular}{lcccc}
\hline Property & Unit & Gasoline & Methanol & Ethanol \\
\hline Typical formula & - & $\mathrm{C}_{8} \mathrm{H}_{18}$ & $\mathrm{CH}_{3} \mathrm{OH}$ & $\mathrm{C}_{2} \mathrm{H}_{5} \mathrm{OH}$ \\
Carbon content & wt. $\%$ & 84.21 & 37.50 & 52.17 \\
Hydrogen content & $\mathrm{wt} \%$ & 15.79 & 12.50 & 13.04 \\
Oxygen content & $\mathrm{wt} \%$ & 0 & 50.00 & 34.79 \\
Carbon/Hydrogen ratio & - & 5.333 & 3.000 & 4.000 \\
Molecular weight & $\mathrm{g} / \mathrm{mol}$ & 114.0 & 32.0 & 46.0 \\
Density at $20^{\circ} \mathrm{C}$ & $\mathrm{g} / \mathrm{cm}^{3}$ & 0.715 & 0.791 & 0.793 \\
Motor octane number & - & 87.2 & 91 & 92 \\
Research octane number & - & 95 & 112 & 111 \\
Lower heating value & $\mathrm{MJ} / \mathrm{kg}$ & 43.00 & 20.05 & 26.95 \\
Copper strip corrosion $\left(3 \mathrm{~h}\right.$ at $\left.50^{\circ} \mathrm{C}\right)$ & Degree of corrosion & $1 \mathrm{a}$ & - & $1 \mathrm{a}$ \\
Auto ignition temperature & ${ }^{\circ} \mathrm{C}$ & 257 & 480 & 425 \\
Latent heat of evaporation & $\mathrm{kJ} / \mathrm{L}$ & 223 & 920 & 725 \\
Kinematic viscosity at $40^{\circ} \mathrm{C}$ & $\mathrm{cSt}$ & 0.494 & - & 1.221 \\
Water content & $\mathrm{ppm}$ & 775 & - & $<0.1 \%$ \\
Lead & $\mathrm{g} / \mathrm{L}$ & 0.004 & - & 0 \\
Stoichiometric air/fuel ratio & - & $10.5-14.1$ & $15.5-13.7$ & $13.2-14.1$ \\
Stoichiometric laminar flame speed & $\mathrm{m} / \mathrm{s}$ & 0.34 & 0.43 & 0.41 \\
\hline
\end{tabular}

Ethanol and methanol are alternative fuels that can be used in ICEs with different methods. In the present research, gasoline, ethanolgasoline blend (E10), and methanol-gasoline blend (M10) were used in a single-cylinder, four-stroke, water-cooled, SI engine at different loads (from $25 \%$ to $100 \%$ ) without changing the CR to achieve the performance and emission values. The technical specifications of the tested engine were tabulated in Table 2.

Table 2. Technical specifications of the experimental engine

\begin{tabular}{lc}
\hline Parameters & Specification \\
\hline Engine supplier & Apex Innovations Pvt. Ltd. \\
Brand-Model & Kirloskar- TV1 \\
Cylinder number & 1 \\
Engine cycle & 4 \\
Maximum engine power & $4.5 \mathrm{~kW}$ at $1800 \mathrm{rpm}$ \\
Engine speed range & $1200-1800 \mathrm{rpm}$ \\
Powertrain & Camshaft in the block with pushrod \\
Valve system & 2 valves per cylinder \\
Type of fuel injection & Carburator \\
Ignition & Spark-ignition \\
Cooling system & Water-cooled \\
Swept volume & $661.45 \mathrm{~cm} 3$ \\
Bore x Stroke & 87.50 mm x $110.00 \mathrm{~mm}$ \\
Compression ratio & Variable: $6-10$ \\
Exhaust valve opening advance & $35.5^{\circ} \mathrm{BBDC}$ \\
Exhaust valve closing delay & $4.5^{\circ} \mathrm{ATDC}$ \\
Spark timing & $10^{\circ} \mathrm{BTDC}$ \\
Intake valve opening advance & $4.5^{\circ} \mathrm{BTDC}$ \\
Intake valve closing delay & $35.5^{\circ} \mathrm{ABDC}$ \\
\hline
\end{tabular}


Engine maintenance was carried out prior to the experiments commenced. Before each test, the engine was run for 30 minutes with the fuel used in the relevant test in order for it to be stabilized. After the engine was stabilized, the tests were performed in the experimental setup at a fixed speed of $1500 \mathrm{rpm}$ and four different engine loading conditions. The pictorial view of the experimental setup was presented in Figure 1. Fuel consumption was measured volumetrically, and mass fuel consumption was determined by multiplying the measured volumetric flow rate by the fuel density. The tests were repeated four times to verify the experimental data obtained for each fuel type, and the average values were used in the analyses.

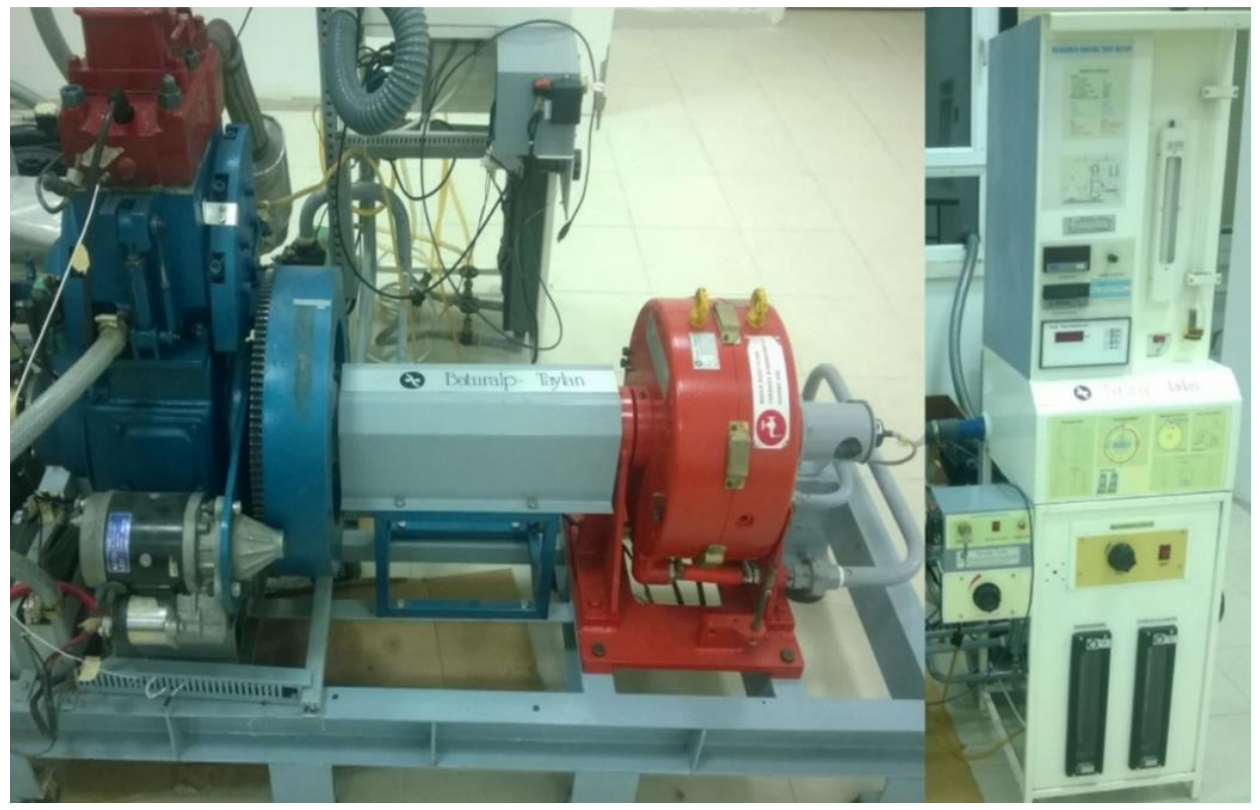

Figure 1. Pictorial view of the experimental setup

K-test brand gas analyszer was used for the measurement of exhaust gas emissions. The measurement range and sensitivities of the devices used during the experimental studies can be observed in Table 3. Before conducting tests with each type of fuel, the exhaust emission device was subjected to zeroing, and the sampling probe was cleaned with compressed air. The emission measurements were made at 60 seconds intervals to avoid exhaust emission measurement errors. The cooling water flow rate of the engine was measured by means of a liquid flowmeter. Pt 100 type temperature measurement probes were used to determine the engine cooling water inlet and outlet temperatures. EGTs were measured using a K-type thermocouple. During the experimental studies, ambient temperature and humidity were continuously controlled using a digital thermometer and a humidity measurement device. Table 3 also exhibited the uncertainties of the calculated and measured parameters.

Table 3. The uncertainties of the calculated and measured parameters

\begin{tabular}{lccc}
\hline Parameter & Measurement Range & Accuracy & Uncertainty (\%) \\
\hline Brake torque & $0-90 \mathrm{Nm}$ & $\pm 0.1 \mathrm{Nm}$ & \pm 0.88 \\
Engine speed & $0-9999 \mathrm{rpm}$ & $\pm 1 \mathrm{rpm}$ & \pm 0.83 \\
Engine load & $0-12 \mathrm{~kg}$ & $\pm 0.1 \mathrm{~kg}$ & \pm 0.07 \\
Air flow rate & - & - & \pm 0.80 \\
Digital stopwatch & - & $\pm 0.2 \mathrm{~s}$ & \pm 0.20 \\
Burette system & $0-100 \mathrm{cc}$ & $\pm 0.1 \mathrm{cc}$ & \pm 1.00 \\
Fuel flow rate & - & - & \pm 0.90 \\
Liquid flowmeter & $40-400 \mathrm{~L} / \mathrm{h}$ & $\pm 5 \mathrm{~L} / \mathrm{h}$ & \pm 1.25 \\
Temperature & - & $\pm 0.1{ }^{\circ} \mathrm{C}$ & \pm 1.00 \\
$\mathrm{BTE}$ & - & - & \pm 1.55 \\
$\mathrm{CO}$ & $0-10 \%$ vol. & $\pm 0.001 \%$ & \pm 0.98 \\
$\mathrm{HC}$ & $0-4000 \mathrm{ppm}$ & $\pm 1 \mathrm{ppm}$ & \pm 1.25 \\
$\mathrm{CO}$ & $0-20 \% \mathrm{vol}$. & $\pm 0.01 \%$ & \pm 0.85 \\
$\mathrm{NO}_{\mathrm{X}}$ & $0-4000 \mathrm{ppm}$ & $\pm 1 \mathrm{ppm}$ & \pm 0.80 \\
$\mathrm{O}_{2}$ & $0-25 \% \mathrm{vol}$. & $\pm 0.01 \%$ & \pm 0.80 \\
\hline
\end{tabular}

\subsection{Theoretical consideration}

In the analyses conducted in this current study, it is assumed that the engine runs steadily, and the inlet air and exhaust gases formed as a result of combustion are ideal gases. Moreover, potential and kinetic energies of fuel, combustion air, and exhaust gases were neglected in the energy and exergy analyses. In the analysis, the reference state was identified as $\mathrm{T}_{0}=25^{\circ} \mathrm{C}$ and $\mathrm{P}_{0}=1 \mathrm{~atm}$. 
SI engines convert the chemical energy of fuel into mechanical energy after the combustion process. The test engine was accepted as an open thermodynamic system with continuous flow, and its energy balance is given below in Eq. (1). In this statement, $\dot{E}_{f u e l}$ includes the fuel energy flow, $\dot{W}$ identifies the engine power, $\dot{Q}_{e q}$ is the exhaust energy flow, $\dot{Q}_{c}$ indicates the energy flow going to cooling water, and $\dot{Q}_{a}$ represents the heat flow going from the engine surface to the environment and other losses.

$\dot{E}_{f u e l}-\dot{W}=\dot{Q}_{e q}+\dot{Q}_{c}+\dot{Q}_{a}$

The exergy balance for the control volume shown in Figure 2 is given in Eq. (2). Here, $\dot{E} x_{f u e l}$ indicates the exergy of the tested fuel, $\dot{E} x_{a i r}$ is the inlet air exergy, $\dot{E} x_{e q}$ is the exhaust exergy, $\dot{E} x_{c}$ is the cooling water, and $\dot{E} x_{a}$ indicates the engine surface-related exergy flows. Furthermore, $\dot{E} x_{W}$ expresses the exergetic power, and $\dot{E} x_{\text {dest }}$ identifies the irreversibility (exergy destruction) (Gümüş et al., 2013). In the calculations in the present study, it was accepted that $\dot{E} x_{\text {air }}=0$. Combustion air enters the test engine under environmental conditions. Accordingly, the exergy of the air is considered as zero by assuming that the air is found dead. Thus, it can be said that the input exergy consists of the exergy of the fuel.

$\dot{E} x_{f u e l}+\dot{E} x_{a i r}=\dot{E} x_{e q}+\dot{E} x_{W}+\dot{E} x_{c}+\dot{E} x_{a}+\dot{E} x_{d e s t}$

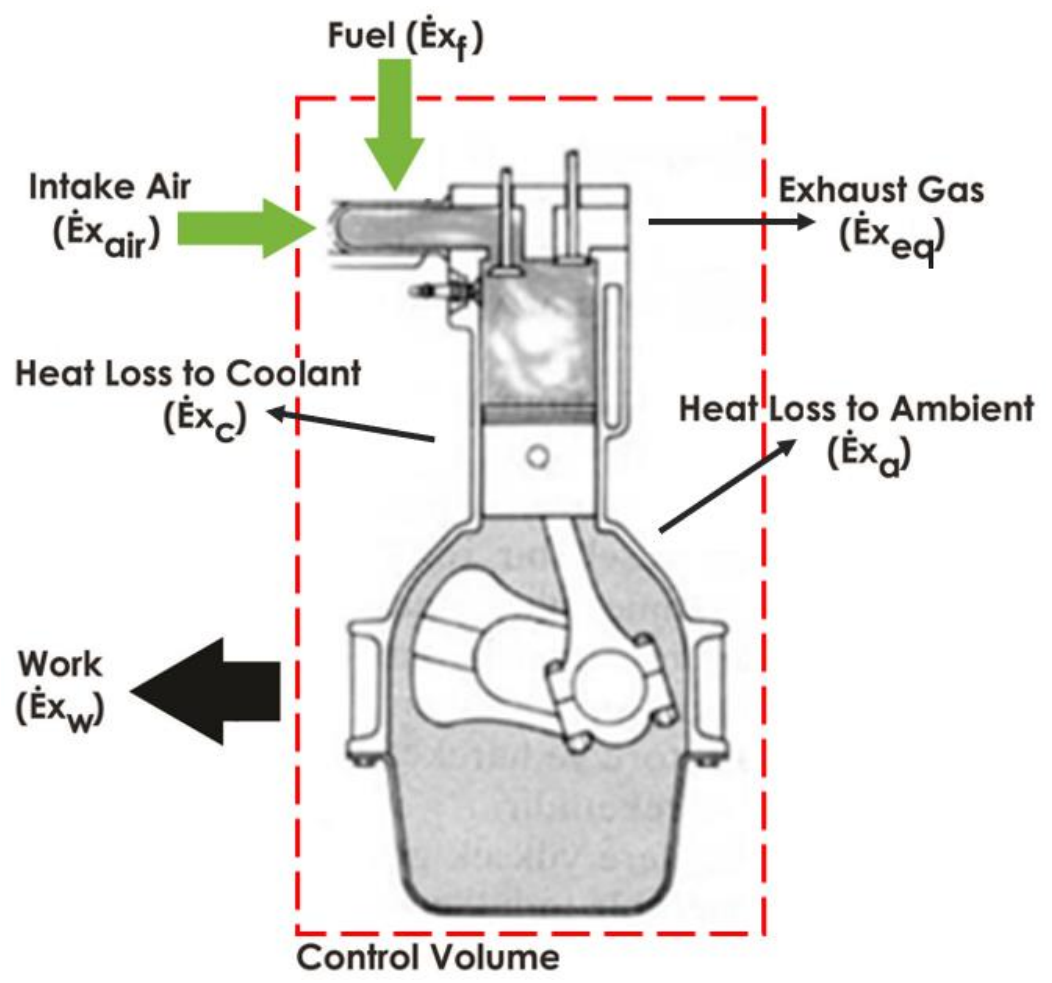

Figure 2. Schematic view of the control volume

When calculating the fuel exergy with using Eq. (3) called input exergy, only chemical exergy was taken into account (Çakmak et al., 2017; Chaudhary et al., 2020). Here, $\dot{m}_{f u e l}$ is the mass flow of the fuel, $H_{u}$ is the lower heating value of the fuel, and $\varphi$ is the chemical exergy factor. The chemical exergy factor was computed in Eq. (4) according to the mass ratio of hydrogen, oxygen, carbon, and sulfur contents in the composition of the fuel (Çakmak et al., 2017). Exergetic power $\left(\dot{E} x_{w}\right)$ is taken equal to the engine power.

$\dot{E} x_{f u e l}=\dot{m}_{f u e l} H_{u} \varphi$

$\varphi=1.0401+0.1728 \frac{h}{c}+0.0432 \frac{o}{c}+0.2169 \frac{s}{c}\left(1-2.0628 \frac{h}{c}\right)$

$\dot{E} x_{w}=\dot{W}$

The exhaust exergy flow is the sum of the chemical and thermomechanical exergies of the exhaust gases, as given in Eq. (6). Here, $\mathrm{T}_{3}$ is the exhaust inlet temperature, $\mathrm{P}_{3}$ is the exhaust inlet pressure, and $\mathrm{C}_{\mathrm{peq}}$ is the specific heat at constant pressure. The chemical exergy of the exhaust gases can be found from Eq. (8). When calculating chemical exergy, $(\bar{R})$ is the gas constant, (y) is the exhaust gas mole 
fraction, and $\left(y^{e}\right)$ is the component mole fraction given in Table 4 in the reference ambient conditions (Caliskan et al., 2009; Aghbashlo et al., 2016).

$$
\begin{aligned}
& \dot{E} x_{e q}=\dot{E} x_{e q, c h}+\dot{E} x_{e q, t} \\
& \dot{E} x_{e q, t}=\left(\dot{m}_{f u e l}+\dot{m}_{\text {air }}\right)\left[C_{\text {peq }}\left(T_{3}-T_{0}-T_{0} \ln \left(\frac{T_{3}}{T_{0}}\right)\right)+R T_{0} \ln \left(\frac{P_{3}}{P_{0}}\right)\right] \\
& \dot{E} x_{e q, c h}=\bar{R} T_{0} \ln \frac{y}{y^{e}}
\end{aligned}
$$

Table 4. Mole fraction of the reference environment (Moran et al., 2010).

\begin{tabular}{lc}
\hline Reference component & Mol Fractions (\%) \\
\hline $\mathrm{N}_{2}$ & 75.6700 \\
$\mathrm{O}_{2}$ & 20.3500 \\
$\mathrm{H}_{2} \mathrm{O}$ & 3.03000 \\
$\mathrm{CO}_{2}$ & 0.03450 \\
$\mathrm{SO}_{2}$ & 0.00020 \\
$\mathrm{CO}$ & 0.00070 \\
$\mathrm{H}_{2}$ & 0.00005 \\
Others & 0.91455 \\
\hline
\end{tabular}

The actual combustion equations of G100, E10, and M10 fuels are needed when calculating the exhaust exergy flow. The theoretical combustion equations of these fuels are given in Eqs. (9-11). The emission data measured in the tests to obtain the actual combustion equation were used in Eq. (12) (da Costa et al., 2019; Taghavifar et al., 2019; Verhelst et al., 2019).

$$
\begin{aligned}
& \mathrm{C}_{8} \mathrm{H}_{18}+12.5\left(\mathrm{O}_{2}+3.76 \mathrm{~N}_{2}\right) \rightarrow 8 \mathrm{CO}_{2}+9 \mathrm{H}_{2} \mathrm{O}+47 \mathrm{~N}_{2} \\
& \mathrm{C}_{2} \mathrm{H}_{5} \mathrm{OH}+3\left(\mathrm{O}_{2}+3.76 \mathrm{~N}_{2}\right) \rightarrow 2 \mathrm{CO}_{2}+3 \mathrm{H}_{2} \mathrm{O}+11.28 \mathrm{~N}_{2} \\
& \mathrm{CH}_{3} \mathrm{OH}+1.5\left(\mathrm{O}_{2}+3.76 \mathrm{~N}_{2}\right) \rightarrow \mathrm{CO}_{2}+2 \mathrm{H}_{2} \mathrm{O}+5.64 \mathrm{~N}_{2} \\
& \left(\mathrm{C}_{x} \mathrm{H}_{y} \mathrm{O}_{z}\right)+a\left(\mathrm{O}_{2}+3.76 \mathrm{~N}_{2}\right) \rightarrow b \mathrm{CO}+c \mathrm{CO}_{2}+d \mathrm{O}_{2}+e \mathrm{H}_{2} \mathrm{O}+g \mathrm{~N}_{2}
\end{aligned}
$$

The exergy loss caused by cooling water is given in Eq. (13). Here, $\dot{m}_{c}$ is the cooling water mass flow rate, $\mathrm{T}_{\text {cout }}$ is the cooling exist water temperature, $T_{\mathrm{cin}}$ is the cooling water entrance temperature, $\mathrm{T}_{0}$ is the dead state temperature, and $\mathrm{C}_{\mathrm{pc}}$ is the specific heat at constant pressure (Aghbashlo et al., 2015).

$\dot{E} x_{c}=\dot{m}_{c} C_{p c}\left(T_{\text {cout }}-T_{\text {cin }}-T_{0} \ln \left(\frac{T_{\text {cout }}}{T_{\text {cin }}}\right)\right)$

Exergies originated from the engine surface can be calculated from Eq. (14). Here, $\dot{Q}_{a}$ is the heat loss of the engine surface calculated from the energy balance, and $T_{a}$ is the average engine surface temperature (Douvartzides et al., 2004).

$\dot{E} x_{a}=\dot{Q}_{a}\left(1-\frac{T_{0}}{T_{a}}\right)$

After determining all exergy flow values from Eqs. (3, 5, 6, 13, 14), exergy destruction can be calculated using Eq. (2). Exergy efficiency is computed using Eq. (15) (Khanali et al., 2013).

$\Psi=\frac{\dot{E} x_{W}}{\dot{E} x_{\text {fuel }}}$

The sustainable index can be calculated with Eq. (16) by using exergy efficiency ( $\Psi)$. Entropy production can be found from Eq. (17) by using exergy destruction and dead state temperature (Aghbashlo et al., 2017).

$$
\begin{aligned}
& S I N=\frac{1}{1-\Psi} \\
& \dot{S}_{\text {gen }}=\left(\frac{\dot{E} x_{\text {dest }}}{T_{0}}\right)
\end{aligned}
$$




\section{Results and Discussion}

In this study, engine performance and exhaust emission tests were performed firstly by using pure gasoline and then by using the fuel blends obtained by blending volumetrically $10 \%$ ethanol and methanol as alcohol with pure gasoline. Fuel consumption in ICEs generally depends on operating parameters such as load and speed. In this study, fuel blends were tested at different engine loads. As is observed in Figure 3, the consumption of E10 and M10 alcohol-gasoline fuel blends is higher than the consumption of G100 pure gasoline fuel. The reason for this is that ethanol and methanol have lower heating values than gasoline. At all engine loads, E10 and M10 blends were found to be consumed approximately by $8.5 \%$ and $5.5 \%$ more, respectively, than pure gasoline fuel.

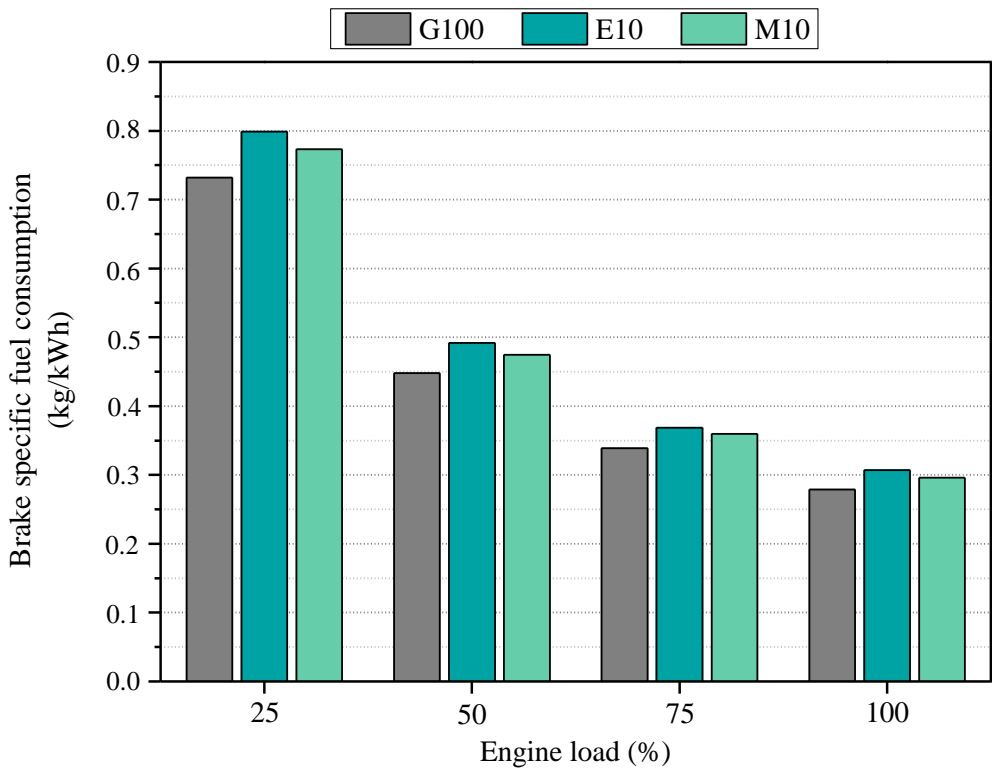

Figure 3. BSFC values for tested fuels at various engine loads

One of the greenhouse gases that cause global warming is $\mathrm{CO}_{2}$ (Kim et al., 2016). The $\mathrm{CO}_{2}$ emission figures for all tested fuel samples under various engine loads were portrayed in Figure 4. With the increase in engine load, $\mathrm{CO}_{2}$ emissions decrease in all fuel blends. Since ethanol and methanol have lower $\mathrm{C} / \mathrm{H}$ ratios than gasoline, as a result of combustion, they emitted a smaller amount of $\mathrm{CO}_{2}$ compared to gasoline, as is seen in Fig. 4. The average amount of emission decreased with the utilization of E10 and M10 blends compared to pure gasoline fuel was obtained to be $13 \%$ and $8 \%$, respectively.

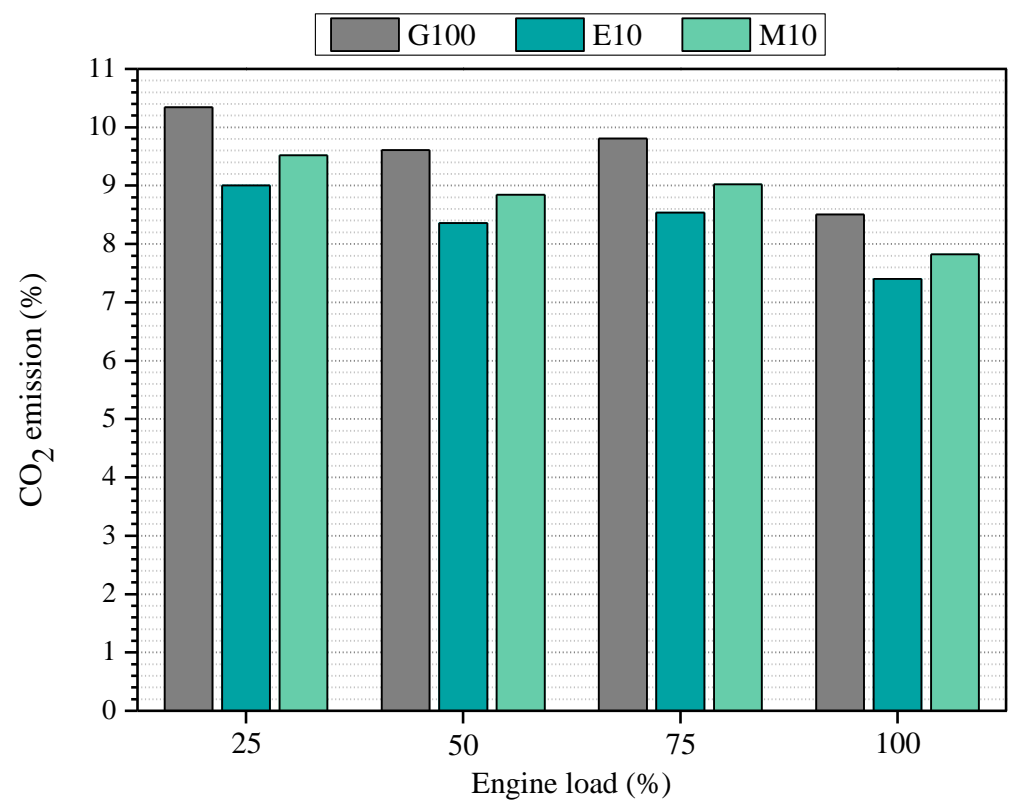

Figure 4. The change of $\mathrm{CO}_{2}$ emissions for tested fuels at various engine loads

The effect of fuel blends on $\mathrm{CO}$ emission is observed in Figure 5. The molecular structure of the fuel, air-fuel ratio, cylinder gas temperature, and turbulence in the combustion chamber effect on the CO emission (Pulkrabek, 2004; Elsemary et al., 2016). In terms 
of CO emission, the average amount of decrease in the case of using E10 and M10 blends compared to gasoline is $12 \%$ and $10 \%$, respectively. Ethanol and methanol contain oxygen in their chemical structures. With the increase in the ratio of ethanol and methanol in the fuel blends used in the study, the air-fuel ratio needed for complete combustion also decreases. Accordingly, the oxygen content of the fuel is observed to be quite useful in combustion. However, even though the oxygen content of methanol is higher than that of ethanol, a further decrease in $\mathrm{CO}$ emissions with ethanol was achieved. This situation can be explained by the latent heat of evaporation characteristics of the tested fuels. The fact that the latent heat of evaporation of methanol is higher than that of ethanol and thereby it may have slowed the oxidation rate of the fuel by reducing the cylinder gas temperature and increased $\mathrm{CO}$ emission slightly (Awad et al., 2018).

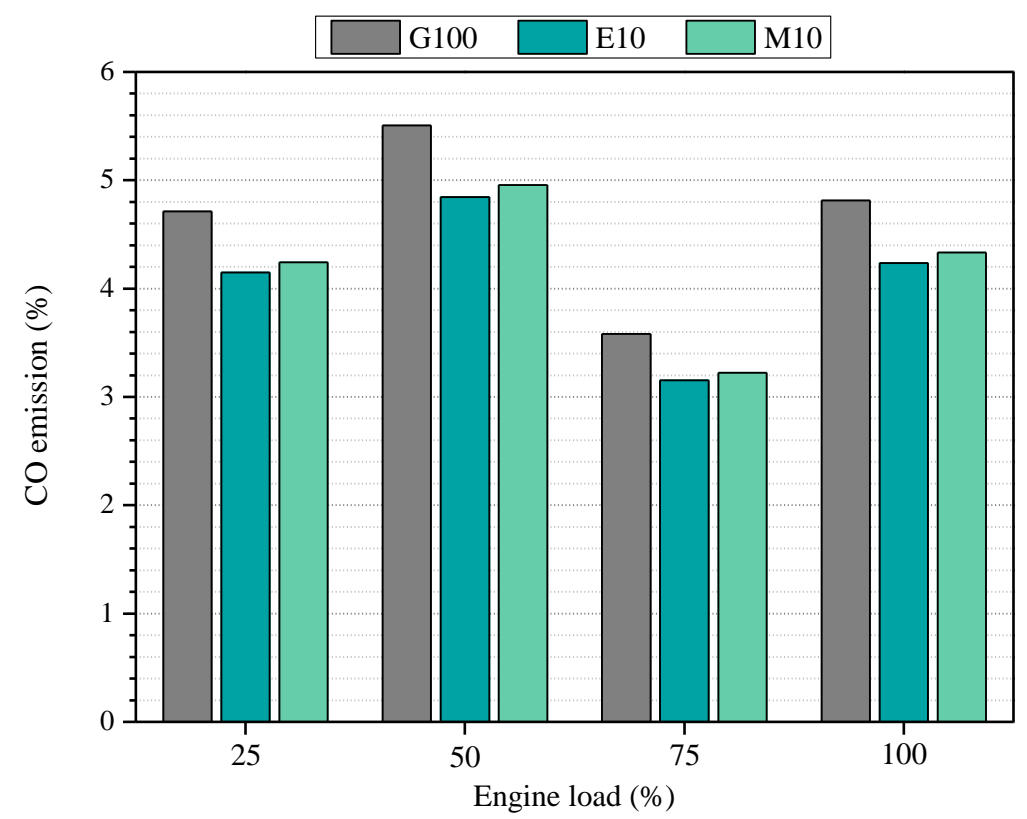

Figure 5. The change of $\mathrm{CO}$ emissions for tested fuels at various engine loads

$\mathrm{HC}$ emission is an indicator that reflects the incomplete combustion products inside the combustion chamber and occurs due to rich mixture, low combustion temperature, crevice volume, extinguishment of the flame front on the combustion chamber surfaces, and engine lubricating oil (Tangestani et al., 2020; Uslu et al., 2020). HC emissions that occurred in the study, depending on the engine load, are presented in Figure 6. In the use of E10 and M10, the average amount of HC emissions decreased compared to gasoline was determined to be $39 \%$ and $35 \%$, respectively. The main reason for lower HC emissions in ethanol-gasoline and methanol-gasoline blends is that ethanol and methanol contain an excessive amount of oxygen molecules in their structure.

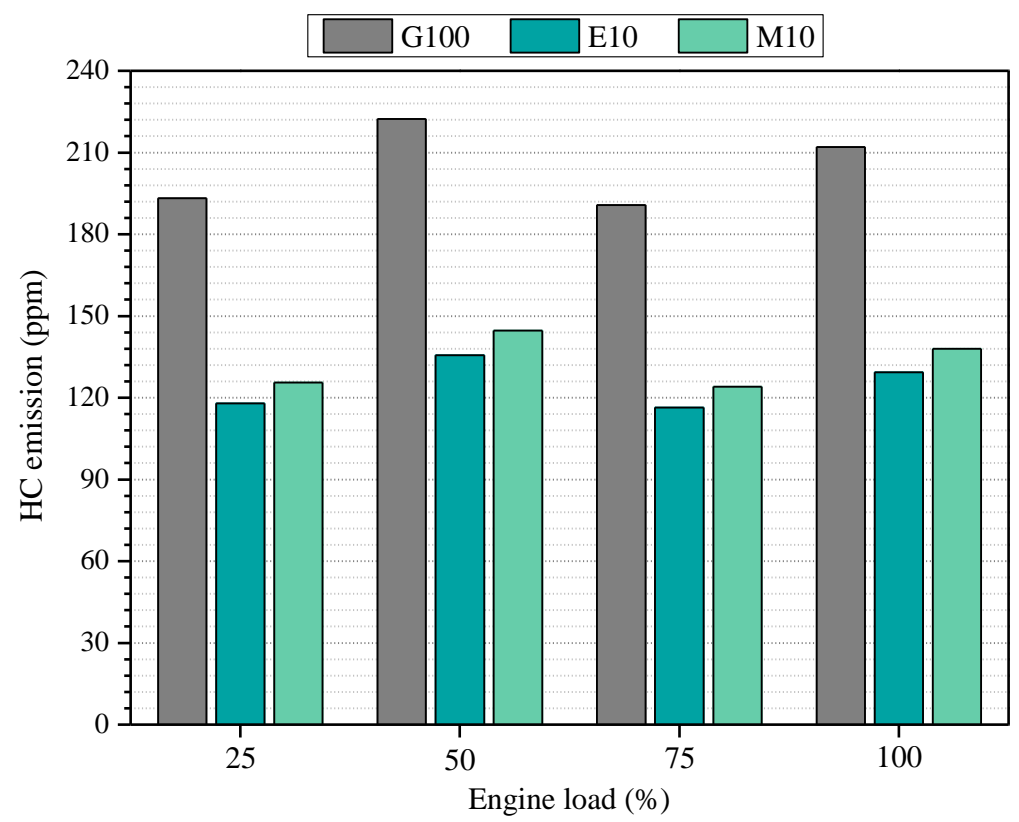

Figure 6. The change of $\mathrm{HC}$ emissions for tested fuels at various engine loads 
$\mathrm{NO}_{\mathrm{X}}$ emissions occur as a result of the nitrogen in the air reacting with oxygen at high temperatures during the combustion process inside the engine cylinder (Fletcher et al., 1971; Şimşek et al., 2020). The alterations of the NOx emissions for all the tested fuel samples according to the engine load was presented in Figure 7. When Figure 7 is examined, $\mathrm{NO}_{\mathrm{x}}$ emission is observed to increase in all fuels with the increase in engine load up to $75 \%$, and it is observed to decrease at $100 \%$ engine load. As seen, fewer $\mathrm{NO}_{\mathrm{X}}$ emissions were released into the atmosphere when the utilization of E10 and M10 fuel blends in the tested engine compared to G100 fuel. The average amount of decrease in $\mathrm{NO}_{\mathrm{x}}$ emissions in the use of $\mathrm{E} 10$ and $\mathrm{M} 10$ fuels compared to gasoline is $9 \%$ and $6 \%$, respectively. The main reason for this is that the latent heat of evaporation values of ethanol and methanol is higher than that of gasoline, and their calorific values are lower in comparison with gasoline. The fact that the high latent heat of evaporation caused to decrease the temperature at the end of the combustion reaction due to the cooling effect resulting in withdrawing the heat from the regions inside the cylinder.

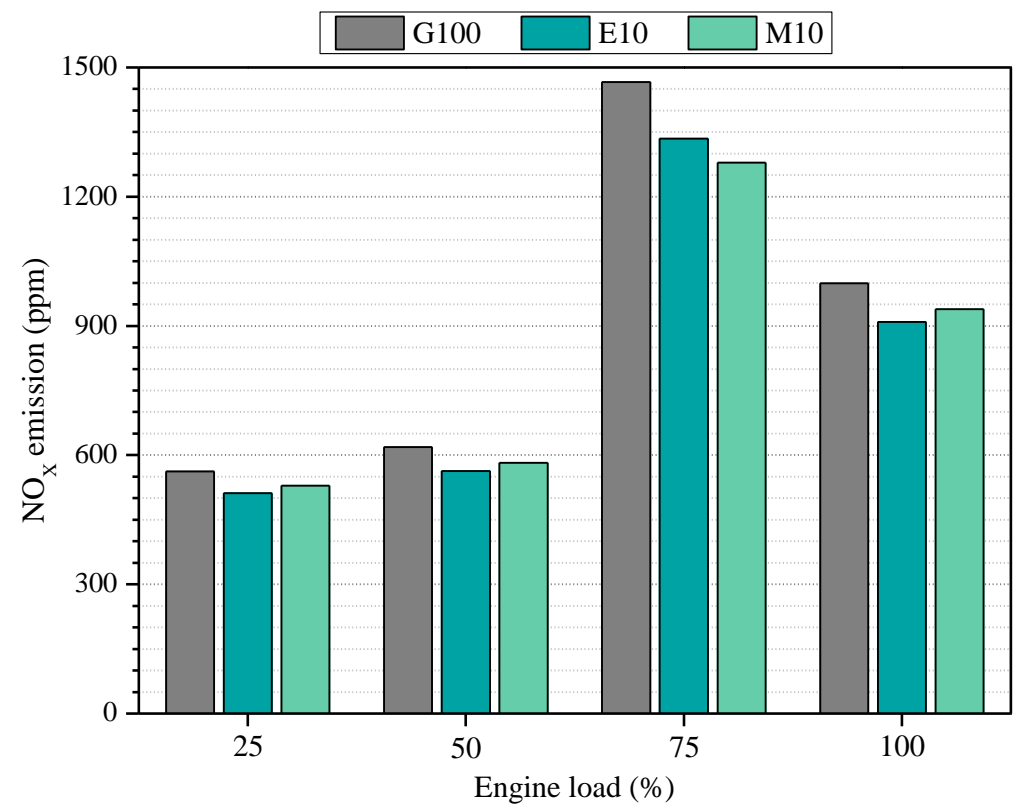

Figure 7. The change of $\mathrm{NO}_{\mathrm{x}}$ emissions for tested fuels at various engine loads

The amount of oxygen contained in the exhaust gas of the test engine used in the study is given in Figure 8. The oxygen contents of E10 and M10 fuel blends are high compared to G100 fuel. Therefore, more oxygen emissions were obtained in the combustion of ethanol and methanol blended fuels. This situation can be explained by the high rates of oxygen molecules contained in the structure of alcohols. Since pure gasoline fuel does not contain oxygen in its molecular structure, it caused the lowest $\mathrm{O}_{2}$ emissions.

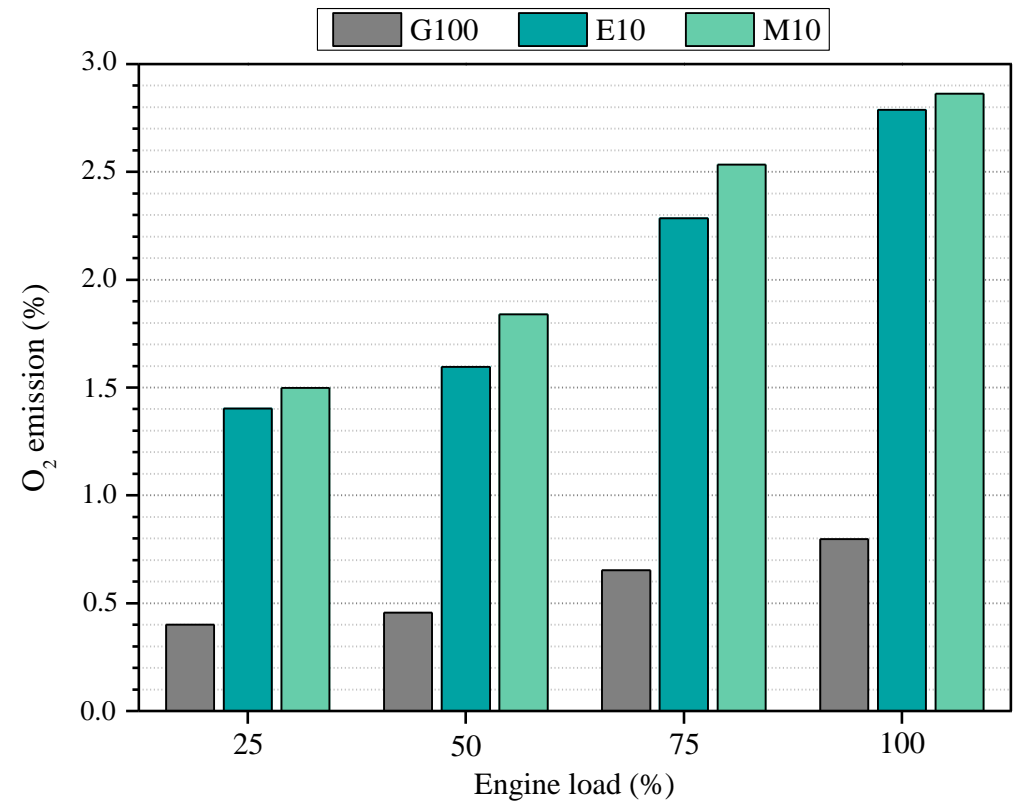

Figure 8. The change of oxygen emissions for tested fuels at various engine loads 
Energy analysis applied to SI engines gives the distribution of fuel energy flow by various engine components. Exergy analysis applied after this analysis enables the comparison of engine performance with maximum performance. The energy flow, heat loss, net power, and energy efficiency of the fuels were calculated from the energy analysis, and the results were presented in Table 5. Power and efficiency increase in all fuel blends with an increase in engine load. Compared to other fuel samples, G100 fuel performed best in energy efficiency at all loads due to the higher energy content. The highest heat losses in all engine loads occurred in E10 fuel.

Table 5. Energy analysis results

\begin{tabular}{cccccccccc}
\hline $\begin{array}{c}\text { Engine } \\
\text { Load } \\
(\boldsymbol{\%})\end{array}$ & \multicolumn{3}{c}{ Input Energy $(\mathbf{k W})$} & \multicolumn{3}{c}{ Total Heat Loss $(\mathbf{k W})$} & \multicolumn{3}{c}{ Energy Efficiency (\%) } \\
\cline { 2 - 9 } & $\mathbf{G 1 0 0}$ & $\mathbf{E 1 0}$ & $\mathbf{M 1 0}$ & $\mathbf{G 1 0 0}$ & $\mathbf{E 1 0}$ & $\mathbf{M 1 0}$ & $\mathbf{G 1 0 0}$ & $\mathbf{E 1 0}$ & M10 \\
\hline 25 & 7.50 & 7.90 & 7.50 & 6.64 & 7.04 & 6.64 & 11.44 & 10.89 & 11.44 \\
50 & 9.22 & 9.73 & 9.25 & 7.50 & 8.01 & 7.53 & 18.69 & 17.68 & 18.63 \\
75 & 10.34 & 10.81 & 10.38 & 7.78 & 8.26 & 7.82 & 24.70 & 23.60 & 24.60 \\
100 & 11.34 & 11.99 & 11.38 & 7.93 & 8.60 & 7.97 & 30.01 & 28.33 & 29.90 \\
\hline
\end{tabular}

In the exergy analysis conducted in the present work, the quantities, which are given in Table 6 and which belong to different fuel blends, were calculated. While calculating the exhaust exergy flow, the actual combustion equations of the fuels given in Table 7 were found according to the values obtained in the engine tests, and the total exergies of the exhaust gases formed as a result of combustion were determined.

Fuel exergy flow increases with increasing engine load in all fuel blends. Methanol has a lower heating value than ethanol. However, exergy flow is higher since the chemical exergy factor is more significant compared to ethanol by $12 \%$. In the test fuels, EGTs increased with an increase in engine load. When the exhaust emission exergy flow was examined, it was determined that E10 and M10 fuels caused fewer pollutant emissions than G100 fuel. The burn of more fuel due to the increase in the load increases cooling water exergy flows. Accordingly, since the amount of heat transferred from the cylinder wall increases with the increase in fuel consumption, the temperatures of the cooling fluid and engine surface increase. This situation increases the exergy rate transferred to the engine cooling system. The exergy transfer rate from the engine surface to the ambient air increased due to the increase in fuel consumption in SI engines and thereby, the increase in the cylinder temperatures.

Exergy destruction occurs due to engine load increase (the increase in irreversibility due to the blend formation), heat transfer originating from the engine surface and cooling fluid (entropy production due to heat transfer realized from a finite temperature difference), combustion reaction, and friction (Boles et al., 2014). The increase in engine load increases exergy destruction and accordingly, entropy generation.

Table 6. Exergy analysis results

\begin{tabular}{|c|c|c|c|c|c|c|c|c|c|c|c|c|c|c|c|}
\hline \multirow{2}{*}{$\begin{array}{c}\text { Engine } \\
\text { Load } \\
(\%)\end{array}$} & \multicolumn{3}{|c|}{ Input Exergy (kW) } & \multicolumn{3}{|c|}{$\begin{array}{l}\text { Exergy Loss to } \\
\text { Ambient (kW) }\end{array}$} & \multicolumn{3}{|c|}{$\begin{array}{c}\text { Exhaust Exergy } \\
(\mathbf{k W})\end{array}$} & \multicolumn{3}{|c|}{$\begin{array}{c}\text { Cooling Water } \\
\text { Exergy }(\mathbf{k W})\end{array}$} & \multicolumn{3}{|c|}{$\begin{array}{c}\text { Exergy Destruction } \\
(\mathrm{kW})\end{array}$} \\
\hline & G100 & E10 & M10 & G100 & E10 & M10 & G100 & E10 & M10 & G100 & E10 & M10 & G100 & E10 & M10 \\
\hline 25 & 10.72 & & & 1.82 & 1.76 & 1.77 & 2.61 & & & 0.23 & 0.27 & 0.29 & 5.20 & 7.17 & 7.85 \\
\hline 50 & 18 & 15 & 16. & 2.02 & 1.97 & 2.01 & 2.94 & 2 & 8 & 28 & 1 & 5 & 6.21 & 8.69 & 9.56 \\
\hline 75 & 6 & 17.07 & 18.41 & 2.19 & 2.17 & 2.19 & 3.41 & 2 & 3 & 0.30 & 0. & 0.37 & 6 & 9.04 & 10.18 \\
\hline 100 & 16.19 & 18.95 & 20.19 & 2.41 & 2.39 & 2.37 & 3.68 & 3.23 & 3.40 & 0.33 & 0.36 & 0.41 & 6.37 & 9.57 & 10.60 \\
\hline
\end{tabular}

Table 7. Actual combustion equation coefficients

\begin{tabular}{lccccccc}
\hline \multirow{2}{*}{ Fuel } & Load & \multicolumn{6}{c}{ Real Combustion Equation Coefficients (dimensionless) } \\
\cline { 3 - 8 } & $(\mathbf{\%})$ & $\mathbf{b}$ & $\mathbf{d}$ & $\mathbf{c}$ & $\mathbf{g}$ & $\mathbf{a}$ & $\mathbf{e}$ \\
\hline \multirow{4}{*}{ G100 } & 25 & 2.504 & 0.213 & 0.213 & 44.917 & 11.946 & 9.9700 \\
& 50 & 2.914 & 0.241 & 0.241 & 44.686 & 11.885 & 10.200 \\
& 75 & 2.139 & 0.390 & 0.390 & 51.350 & 13.657 & 12.674 \\
& 100 & 2.891 & 0.479 & 0.479 & 51.598 & 13.723 & 13.380 \\
\hline \multirow{4}{*}{ E10 } & 25 & 2.334 & 0.789 & 0.789 & 48.097 & 12.792 & 11.639 \\
& 50 & 2.715 & 0.895 & 0.895 & 47.744 & 12.698 & 11.622 \\
& 75 & 1.996 & 1.447 & 1.447 & 54.476 & 14.488 & 13.378 \\
& 100 & 2.694 & 1.774 & 1.774 & 54.437 & 14.478 & 13.402 \\
\hline \multirow{4}{*}{ M10 } & 25 & 2.250 & 0.795 & 0.795 & 44.962 & 11.958 & 10.076 \\
& 50 & 2.622 & 0.974 & 0.974 & 44.641 & 11.873 & 9.9200 \\
& 75 & 1.921 & 1.510 & 1.510 & 50.790 & 13.508 & 11.417 \\
& 100 & 2.601 & 1.719 & 1.719 & 51.040 & 13.574 & 11.812 \\
\hline
\end{tabular}


Entropy generation is proportional to exergy destruction. Exergy always disappears due to irreversibilities depending on the second law of thermodynamics. The destructed exergy causes the system to have less efficiency than theoretical efficiency. It is observed in Figure 9 that when the engine load increases in all fuel blends, the in-cylinder temperature, the exergy loss caused by heat transfer, and the total exergy will increase. Since entropy generation increases depending on the engine load, the total exergy destruction also increases. Entropy generation was calculated to be the most in M10 fuel and the least in G100 fuel depending on engine load.

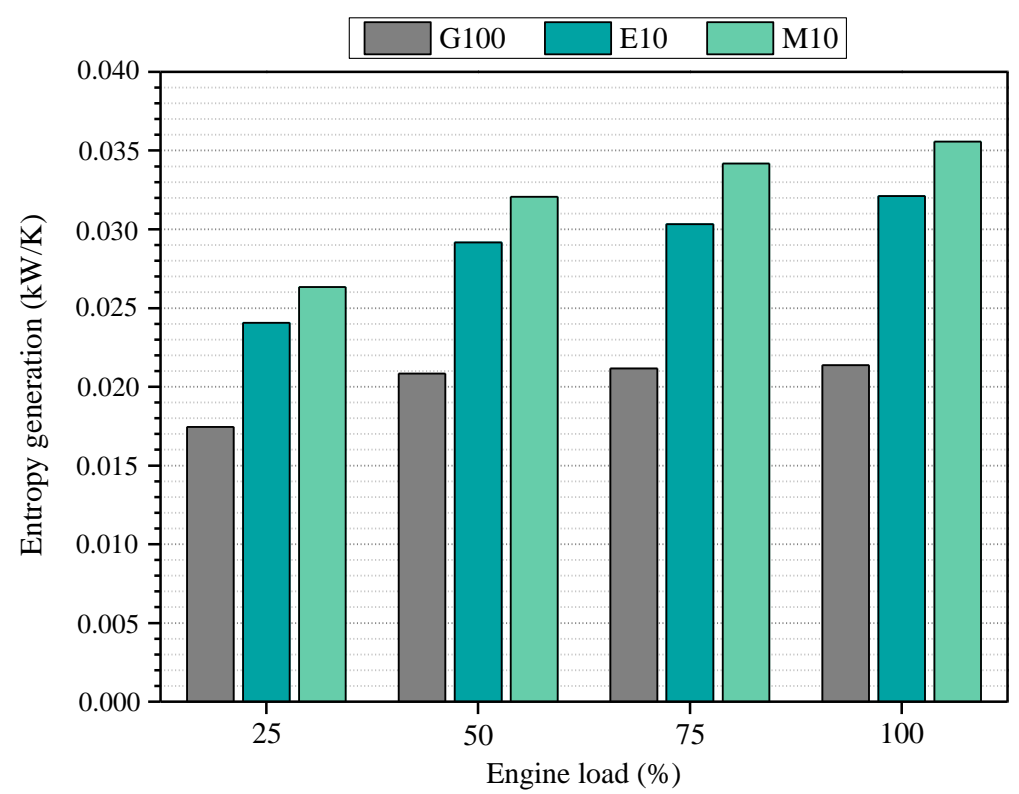

Figure 9. Entropy generation values of tested fuels at various engine loads

How much of the exergy flow of the fuel entering the engine from the intake manifold is converted to power is calculated by exergy efficiency. Exergy efficiency at different loads in the test engine is presented in Figure 10. As alcohol-based fuels are added to gasoline, exergy efficiency decreases depending on the increase in the consumption of fuel. The highest exergy efficiency in all fuels was achieved at 100\% load and the exergy efficiency values of G100, E10 and M10 fuels were calculated at this load, approximately $21 \%$, $17.92 \%$ and $16.85 \%$, respectively.

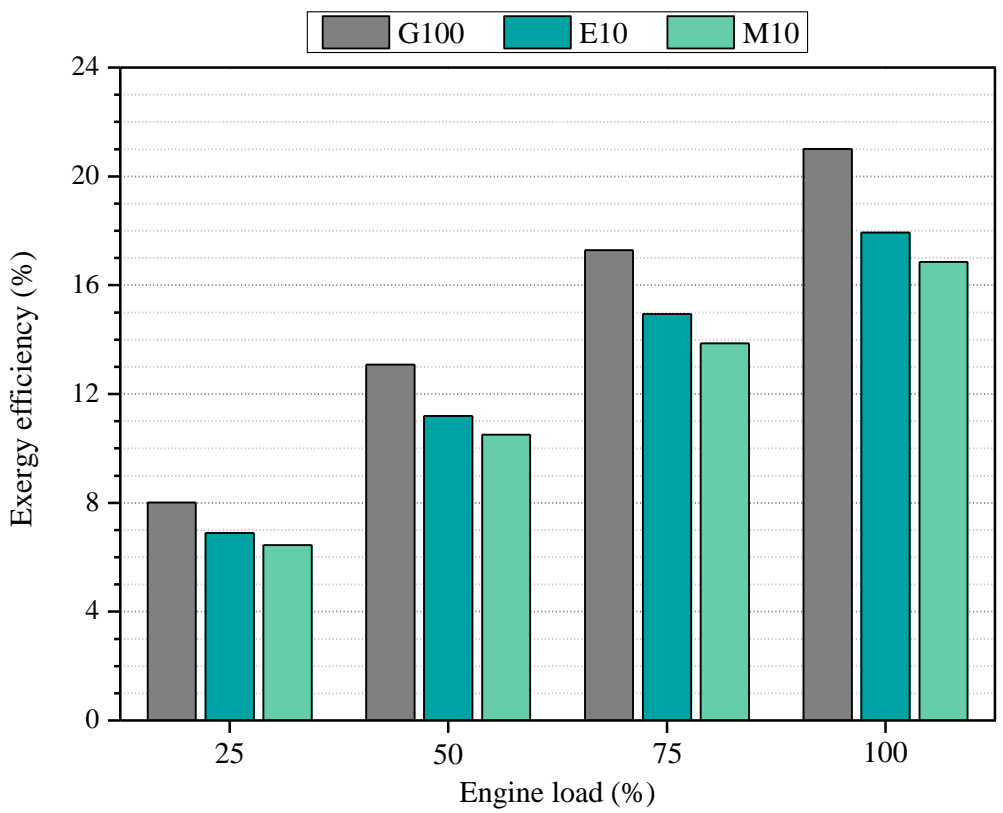

Figure 10. Exergy efficiencies of tested fuels at various engine loads

The sustainability index based on the exergy efficiency of the test engine is given in Figure 11. According to the results, E10 and M10 fuels can be alternatives to G100 fuel. By reducing the thermodynamic irreversibilities that occur in the combustion process, the sustainability index value can be increased. It has been determined that since increasing the engine load increases both energy and exergy efficiencies, the sustainability index also increases. In this study, the highest sustainability index was calculated as 1.26 in G100 fuel at $100 \%$ load. 


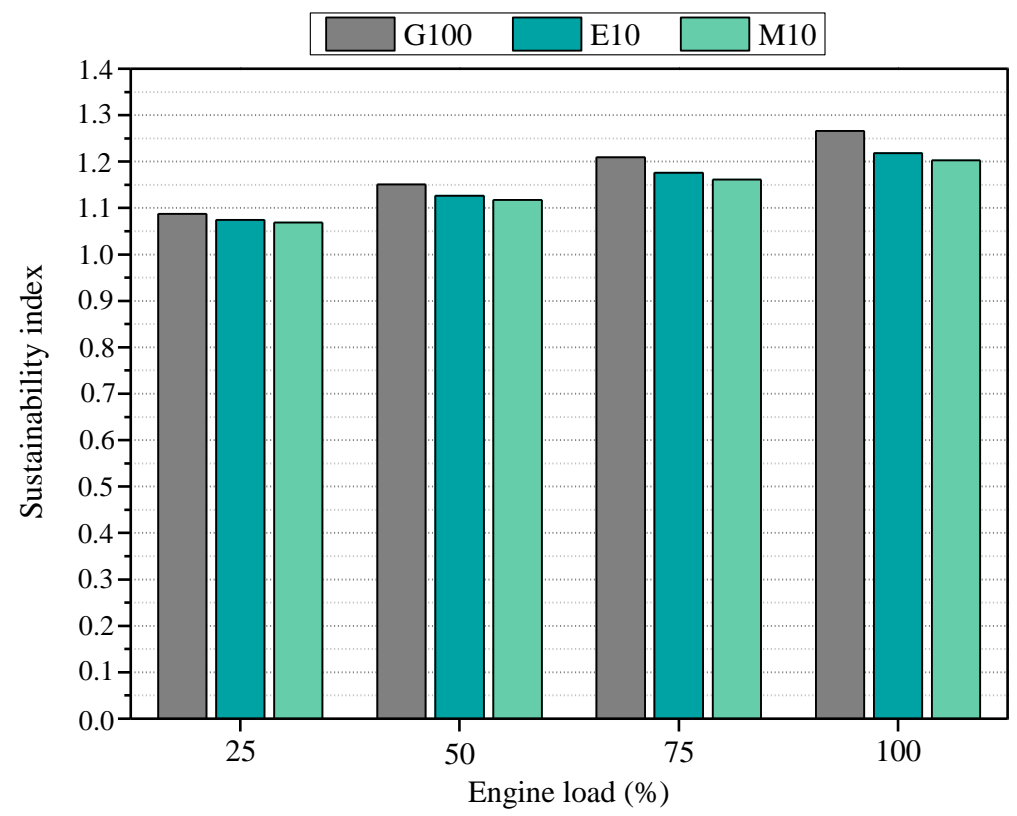

Figure 11. Effect of alcohol addition to gasoline on the sustainability index at various loads

\section{Conclusions}

In the present research, the performance and exhaust emissions of a single-cylinder, four-stroke, SI engine fueled with G100 (100\% gasoline), E10 (10\% ethanol + 90\% gasoline), and M10 (10\% methanol + 90\% gasoline) fuel samples at a constant engine speed of $1500 \mathrm{rpm}$ for four different load values $(25 \%-100 \%)$ were experimentally determined. Afterwards, thermodynamic analyses were conducted with the obtained data.

The consumption of E10 and M10 fuels created by adding alcohol-based additives to pure gasoline was approximately $8.8-9.1 \%$ and 2.4-3.6\% higher in comparison with gasoline, respectively. The lowest BSFC was observed to be as $0.279 \mathrm{~kg} / \mathrm{kWh}$ in G100 fuel at $100 \%$ load.

Due to the inherent oxygen concentrations of ethanol and methanol, $\mathrm{CO}$ and $\mathrm{HC}$ emissions are lesser in comparison with pure gasoline. In experimental studies, the oxygen emissions measured in the exhaust gas of E10 and M10 fuel blends are higher than that of G100 fuel. In the test engine, the lowest $\mathrm{CO}$ emissions in all fuel mixtures occurred at a 75\% load. In this load, E10, M10, and G100 fuels emitted $3.15 \%, 3.22 \%$, and $3.58 \% \mathrm{CO}$ emissions to the environment, respectively. $\mathrm{CO}_{2}$ emission is more environmentally friendly since the $\mathrm{C} / \mathrm{H}$ ratios of alcohols used in the study are lower compared to gasoline. $\mathrm{CO}_{2}$ emission descended with the rise in load. The lowest $\mathrm{CO}_{2}$ emission value was determined to be $7.398 \%$ in E10 fuel. Since the latent heat of evaporation values of ethanol and methanol are higher than that of gasoline, and their heating values are lower compared to gasoline, $\mathrm{NO}_{\mathrm{X}}$ emissions decreased.

Energy and exergy efficiencies increased with the increasing load in fuel blends. At $100 \%$ engine load, the highest energy efficiencies of G100, M10, and E10 fuels were calculated to be as $30.01 \%, 29.90 \%$, and $28.33 \%$, respectively. When the exergy efficiency figures of the tested fuels were evaluated, G100 fuel has performed better than M10 fuel. At the highest engine load operating condition, the exergy efficiency values were calculated to be as $17.92 \%$ for E10 fuel, $16.85 \%$ for M10 fuel, and $21 \%$ for G100 fuel. In comparison with G100 fuel, exergy destruction is higher in E10 and M10 blends, in which the energy content is low, and fuel consumption is high at all engine loads. Entropy generation increases in direct proportion to exergy destruction. The highest entropy generation was occurred to be as $0.0355 \mathrm{~kW} / \mathrm{K}$ in M10 fuel blend at $100 \%$ engine load. According to the calculations of the sustainability index, the highest index coefficient was calculated $1.26 \mathrm{in} \mathrm{G100}$ fuel at 100\% load. It was found as $1.21 \mathrm{in} \mathrm{E10} \mathrm{fuel} \mathrm{and} \mathrm{1.20} \mathrm{in} \mathrm{M10} \mathrm{fuel} \mathrm{with} \mathrm{the} \mathrm{same}$ engine load.

As a result, since E10 and M10 fuel blends exhibit similar performance with G100 fuel, they can be assessed as alternative fuels instead of gasoline out of any modification in the engine. However, energy and exergy destruction should be reduced in order to improve the first and second law efficiencies of SI engines. Therefore, in alternative fuel studies, exergo-economic and exergo-envirenmental analyses can be performed, and evaluations can be made from an environmental and economic perspective.

\section{References}

Agarwal, A. K., Karare, H., Dhar, A. (2014). Combustion, performance, emissions and particulate characterisation of a methanolgasoline blend (gasohol) fuelled medium duty spark ignition transportation engine. Fuel Processing Technology, 121:16-24. 
Aghbashlo, M., Tabatabaei, M., Mohammadi, P., Pourvosoughi, N., Nikbakht, A. M., Goli, S. A. H. (2015). Improving exergetic and sustainability parameters of a DI diesel engine using polymer waste dissolved in biodiesel as a novel diesel additive. Energy Conversion and Management, 105:328-337.

Aghbashlo, M., Tabatabaei, M., Mohammadi, P., Mirzajanzadeh, M., Ardjmand, M., Rashidi, A. (2016). Effect of an emission-reducing soluble hybrid nanocatalyst in diesel/biodiesel blends on exergetic performance of a DI diesel engine. Renewable Energy, 93:353-368.

Aghbashlo, M., Tabatabaei, M., Hosseinpour, S., Khounani, Z., Hosseini, S. S. (2017). Exergy-based sustainability analysis of a low power, high frequency piezo-based ultrasound reactor for rapid biodiesel production. Energy Conversion and Management, 148:759769.

Altun, Ş., Öztop, H. F., Öner, C., Varol, Y. (2013). Exhaust emissions of methanol and ethanol-unleaded gasoline blends in a spark ignition engine. Thermal Science, 17(1):291-297.

Alexandru, D., Ilie, D., Dragos, T. (2017). Evaluation of performance and emissions characteristics of methanol blend (gasohol) in a naturally aspirated spark ignition engine. IOP Conference Series: Materials Science and Engineering, 252(1). doi:10.1088/1757$899 X / 252 / 1 / 012086$

Awad, O. I., Mamat, R., Ibrahim, T. K., Hammid, A. T., Yusri, I. M., Hamidi, M. A., Humada, A. M., Yusop, A. F. (2018). Overview of the oxygenated fuels in spark ignition engine: Environmental and performance. Renewable and Sustainable Energy Reviews, 91:394-408.

Awad, O. I., Mamat, R., Ali, O. M., Sidik, N. A. C., Yusaf, T., Kadirgama, K., Kettner, M. (2018). Alcohol and ether as alternative fuels in spark ignition engine: A review. Renewable and Sustainable Energy Reviews, 82:2586-2605.

Balki, M. K., Sayin, C. (2014). The effect of compression ratio on the performance, emissions and combustion of an SI (spark ignition) engine fueled with pure ethanol, methanol and unleaded gasoline. Energy, 71:194-201.

Balki, M. K., Sayin, C., Canakci, M. (2014). The effect of different alcohol fuels on the performance, emission and combustion characteristics of a gasoline engine. Fuel, 115:901-906.

Barreto, R. A. (2018). Fossil fuels, alternative energy and economic growth. Economic Modelling, 75:196-220.

Bilgin, A., Sezer, I. (2008). Effects of methanol addition to gasoline on the performance and fuel cost of a spark ignition engine. Energy \& Fuels, 22(4):2782-2788.

Boles, M., Cengel, Y. (2014). An Engineering Approach. New York: McGraw-Hil 1 Education.

Bussar, C., Stöcker, P., Cai, Z., Moraes Jr, L., Magnor, D., Wiernes, P., Bracht, N. V., Moser, A., Sauer, D. U. (2016). Large-scale integration of renewable energies and impact on storage demand in a European renewable power system of 2050-Sensitivity study. Journal of Energy Storage, 6:1-10.

Chaudhary, V., Gakkhar, R. P. (2020). Influence of DEE on entropy generation and emission characteristics of DI diesel engine fuelled with WCO biodiesel. Alternative fuels and their utilisation strategies in internal combustion engines, pp. 167-178. Springer, Singapore. ISBN 978-981-15-0417-4

Chen, Y., Ma, J., Han, B., Zhang, P., Hua, H., Chen, H., Su, X. (2018). Emissions of automobiles fueled with alternative fuels based on engine technology: A review. Journal of Traffic and Transportation Engineering (English Edition), 5(4):318-334.

Connolly, D., Lund, H., Mathiesen, B. V. (2016). Smart energy Europe: the technical and economic impact of one potential 100\% renewable energy scenario for the European Union. Renewable and Sustainable Energy Reviews, 60:1634-1653.

Connolly, D., Mathiesen, B. V. (2014). A technical and economic analysis of one potential pathway to a $100 \%$ renewable energy system. International Journal of Sustainable Energy Planning and Management, 1:7-28.

Çakmak, A., Bilgin, A. (2017). Exergy and energy analysis with economic aspects of a diesel engine running on biodiesel-diesel fuel blends. International Journal of Exergy, 24(2-4):151-172.

Çakmak, A., Bilgin, A. (2017). Thermodynamic analysis of the use of corn oil biodiesel in a diesel engine. Gazi University Journal of Science and Technology Part C: Design and Technology, 5(2):87-97. 
Caliskan, H., Tat, M. E., Hepbasli, A. (2009). Performance assessment of an internal combustion engine at varying dead (reference) state temperatures. Applied Thermal Engineering, 29(16):3431-3436.

Canakci, M., Ozsezen, A. N., Alptekin, E., Eyidogan, M. (2013). Impact of alcohol-gasoline fuel blends on the exhaust emission of an SI engine. Renewable Energy, 52:111-117.

da Costa, R. B. R., Hernández, J. J., Teixeira, A. F., Netto, N. A. D., Valle, R. M., Roso, V. R., Coronado, C. J. (2019). Combustion, performance and emission analysis of a natural gas-hydrous ethanol dual-fuel spark ignition engine with internal exhaust gas recirculation. Energy Conversion and Management, 195:1187-1198.

Doğan, B., Erol, D., Yaman, H., Kodanli, E. (2017). The effect of ethanol-gasoline blends on performance and exhaust emissions of a spark ignition engine through exergy analysis. Applied Thermal Engineering, 120:433-443.

Douvartzides, S., Coutelieris, F., Tsiakaras, P. (2004). Exergy analysis of a solid oxide fuel cell power plant fed by either ethanol or methane. Journal of Power Sources, 131(1-2):224-230.

Elfasakhany, A. (2014). The effects of ethanol-gasoline blends on performance and exhaust emission characteristics of spark ignition engines. International Journal of Automotive Engineering, 4(1):609-620.

Elfasakhany, A. (2015). Investigations on the effects of ethanol-methanol-gasoline blends in a spark-ignition engine: performance and emissions analysis. Engineering Science and Technology, an International Journal, 18(4):713-719.

Elfasakhany, A. (2017). Investigations on performance and pollutant emissions of spark-ignition engines fueled with n-butanol-, isobutanol-, ethanol-, methanol-, and acetone-gasoline blends: A comparative study. Renewable and Sustainable Energy Reviews, 71:404-413.

Elsemary, I. M., Attia, A. A., Elnagar, K. H., Elaraqy, A. A. (2016). Experimental investigation on performance of single cylinder spark ignition engine fueled with hydrogen-gasoline mixture. Applied Thermal Engineering, 106:850-854.

Eyidogan, M., Ozsezen, A. N., Canakci, M., Turkcan, A. (2010). Impact of alcohol-gasoline fuel blends on the performance and combustion characteristics of an SI engine. Fuel, 89(10):2713-2720.

Farkade, H. S., Pathre, A. P. (2012). Experimental investigation of methanol, ethanol and butanol blends with gasoline on SI engine. International Journal of Emerging Technology and Advanced Engineering, 2(4):205-215.

Fletcher, R., Heywood, J. (1971). A model for nitric oxide emission from aircraft gas turbine engines. 9th Aerospace Sciences Meeting (p. 123).

Ghazikhani, M., Hatami, M., Safari, B. (2014). The effect of alcoholic fuel additives on exergy parameters and emissions in a two stroke gasoline engine. Arabian Journal for Science and Engineering, 39(3):2117-2125.

Gong, C. M., Huang, K., Jia, J. L., Su, Y., Gao, Q., Liu, X. J. (2011). Improvement of fuel economy of a direct-injection spark-ignition methanol engine under light loads. Fuel, 90(5):1826-1832.

Gravalos, I., Moshou, D., Gialamas, T., Xyradakis, P., Kateris, D., Tsiropoulos, Z. (2013). Emissions characteristics of spark ignition engine operating on lower-higher molecular mass alcohol blended gasoline fuels. Renewable Energy, 50:27-32.

Gümüş, M., Atmaca, M. (2013). Energy and exergy analyses applied to a CI engine fueled with diesel and natural gas. Energy Sources, Part A: Recovery, Utilization, and Environmental Effects, 35(11):1017-1027.

Hansen, K., Mathiesen, B. V., Skov, I. R. (2019). Full energy system transition towards 100\% renewable energy in Germany in 2050. Renewable and Sustainable Energy Reviews, 102:1-13.

Hasan, A. O., Al-Rawashdeh, H., Ala'a, H., Abu-jrai, A., Ahmad, R., Zeaiter, J. (2018). Impact of changing combustion chamber geometry on emissions, and combustion characteristics of a single cylinder SI (spark ignition) engine fueled with ethanol/gasoline blends. Fuel, 231:197-203.

Kapusuz, M., Ozcan, H., Yamin, J. A. (2015). Research of performance on a spark ignition engine fueled by alcohol-gasoline blends using artificial neural networks. Applied Thermal Engineering, 91:525-534. 
Khanali, M., Aghbashlo, M., Rafiee, S., Jafari, A. (2013). Exergetic performance assessment of plug flow fluidised bed drying process of rough rice. International Journal of Exergy, 13(3):387-408.

Kim, Y., Kawahara, N., Tsuboi, K., Tomita, E. (2016). Combustion characteristics and $\mathrm{NO}_{\mathrm{X}}$ emissions of biogas fuels with various $\mathrm{CO}_{2}$ contents in a micro co-generation spark-ignition engine. Applied Energy, 182:539-547.

Koç, M., Sekmen, Y., Topgül, T., Yücesu, H. S. (2009). The effects of ethanol-unleaded gasoline blends on engine performance and exhaust emissions in a spark-ignition engine. Renewable Energy, 34(10):2101-2106.

Krakowski, V., Assoumou, E., Mazauric, V., Maïzi, N. (2016). Feasible path toward 40-100\% renewable energy shares for power supply in France by 2050: A prospective analysis. Applied Energy, 171:501-522.

Li, J., Gong, C. M., Su, Y., Dou, H. L., Liu, X. J. (2010). Effect of injection and ignition timings on performance and emissions from a spark-ignition engine fueled with methanol. Fuel, 89(12):3919-3925.

Li, Y., Gong, J., Deng, Y., Yuan, W., Fu, J., Zhang, B. (2017). Experimental comparative study on combustion, performance and emissions characteristics of methanol, ethanol and butanol in a spark ignition engine. Applied Thermal Engineering, 115:53-63.

Lund, H., Mathiesen, B. V. (2009). Energy system analysis of $100 \%$ renewable energy systems-The case of Denmark in years 2030 and 2050. Energy, 34(5):524-531.

Masum, B. M., Masjuki, H. H., Kalam, M. A., Fattah, I. R., Palash, S. M., Abedin, M. J. (2013). Effect of ethanol-gasoline blend on $\mathrm{NO}_{\mathrm{X}}$ emission in SI engine. Renewable and Sustainable Energy Reviews, 24:209-222.

Mithaiwal, K., Modi, A. J., Gosai, D. (2017). Energy and exergy analysis on SI engine by blend of ethanol with petrol. International Journal of Advanced Engineering Research and Science, AI Publications, 4(4):49-61.

Moran, M. J., Shapiro, H. N., Boettner, D. D., Bailey, M. B. (2010). Fundamentals of engineering thermodynamics. John Wiley \& Sons.

Mwangi, J. K., Lee, W. J., Chang, Y. C., Chen, C. Y., Wang, L. C. (2015). An overview: energy saving and pollution reduction by using green fuel blends in diesel engines. Applied Energy, 159:214-236.

Özcan, H. Çakmak, A., (2018). Comparative exergy analysis of fuel additives containing oxygen and HC based in a spark-ignition (SI) engine. International Journal of Automotive Engineering and Technologies, 7(3):124-133.

Özsezen, A. N., Canakci, M. (2011). Performance and combustion characteristics of alcohol-gasoline blends at wide-open throttle. Energy, 36(5):2747-2752.

Pulkrabek, W. W. (2004). Engineering fundamentals of the internal combustion engine.

Sayah, A. K., Sayah, A. K. (2011). Wind-hydrogen utilisation for methanol production: An economy assessment in Iran. Renewable and Sustainable Energy Reviews, 15(8):3570-3574.

Schifter, I., Diaz, L., Rodriguez, R., Gómez, J. P., Gonzalez, U. (2011). Combustion and emissions behavior for ethanol-gasoline blends in a single cylinder engine. Fuel, 90(12):3586-3592.

Sezer, I., Altin, I., Bilgin, A. (2009). Exergetic analysis of using oxygenated fuels in spark-ignition (SI) engines. Energy \& Fuels, 23(4):1801-1807.

Sezer, İ., Bilgin, A. (2013). Effects of charge properties on exergy balance in spark ignition engines. Fuel, 112:523-530.

Shenghua, L., Clemente, E. R. C., Tiegang, H., Yanjv, W. (2007). Study of spark ignition engine fueled with methanol/gasoline fuel blends. Applied Thermal Engineering, 27(11-12):1904-1910.

Şimşek, S., Saygın, H., Özdalyan, B. (2020). Improvement of fusel oil features and effect of its use in different compression ratios for an SI engine on performance and emission. Energies, 13(7):1824.

Taghavifar, H., Nemati, A., Walther, J. H. (2019). Combustion and exergy analysis of multi-component diesel-DME-methanol blends in HCCI engine. Energy, 187:115951. 
Tangestani, V., Isfahani, A. M. (2020). Experimental evaluation of the performance and exhaust emissions of porous medium diesel and Otto engines. International Journal of Environmental Science and Technology, 17(3):1463-1474.

Thangavelu, S. K., Ahmed, A. S., Ani, F. N. (2016). Review on bioethanol as alternative fuel for spark ignition engines. Renewable and Sustainable Energy Reviews, 56:820-835.

Tian, Z., Zhen, X., Wang, Y., Liu, D., Li, X. (2020). Comparative study on combustion and emission characteristics of methanol, ethanol and butanol fuel in TISI engine. Fuel, 259:116199.

Turner, D., Xu, H., Cracknell, R. F., Natarajan, V., Chen, X. (2011). Combustion performance of bio-ethanol at various blend ratios in a gasoline direct injection engine. Fuel, 90(5):1999-2006.

Uslu, S., Celik, M. B. (2020). Combustion and emission characteristics of isoamyl alcohol-gasoline blends in spark ignition engine. Fuel, 262:116496.

Verhelst, S., Turner, J. W., Sileghem, L., Vancoillie, J. (2019). Methanol as a fuel for internal combustion engines. Progress in Energy and Combustion Science, 70:43-88.

Wu, B., Wang, L., Shen, X., Yan, R., Dong, P. (2016). Comparison of lean burn characteristics of an SI engine fueled with methanol and gasoline under idle condition. Applied Thermal Engineering, 95:264-270.

Yanju, W., Shenghua, L., Hongsong, L., Rui, Y., Jie, L., Ying, W. (2008). Effects of methanol/gasoline blends on a spark ignition engine performance and emissions. Energy \& Fuels, 22(2):1254-1259.

Yücesu, H. S., Topgül, T., Çınar, C., Okur, M. (2006). Effect of ethanol-gasoline blends on engine performance and exhaust emissions in different compression ratios. Applied Thermal Engineering, 26(17-18):2272-2278.

Zhen, X., Wang, Y. (2015). An overview of methanol as an internal combustion engine fuel. Renewable and Sustainable Energy Reviews, 52:477-493. 